NBER WORKING PAPER SERIES

\title{
TECHNICAL CHANGE AND THE RELATIVE DEMAND FOR SKILLED LABOR: THE UNITED STATES IN HISTORICAL PERSPECTIVE
}

\author{
Lawrence F. Katz \\ Robert A. Margo \\ Working Paper 18752 \\ http://www.nber.org/papers/w18752 \\ NATIONAL BUREAU OF ECONOMIC RESEARCH \\ 1050 Massachusetts Avenue \\ Cambridge, MA 02138 \\ February 2013
}

This paper was presented at the "Human Capital and History: The American Record" conference in Cambridge, MA, December 2012. The conference was jointly sponsored by the NBER and the Spencer Foundation. Comments from David Autor, Jeremy Atack, Leah Boustan, Stan Engerman, Carola Frydman, Caitlin Rosenthal, and conference participants are gratefully acknowledged. The views expressed herein are those of the authors and do not necessarily reflect the views of the National Bureau of Economic Research.

At least one co-author has disclosed a financial relationship of potential relevance for this research. Further information is available online at http://www.nber.org/papers/w18752.ack

NBER working papers are circulated for discussion and comment purposes. They have not been peerreviewed or been subject to the review by the NBER Board of Directors that accompanies official NBER publications.

(C) 2013 by Lawrence F. Katz and Robert A. Margo. All rights reserved. Short sections of text, not to exceed two paragraphs, may be quoted without explicit permission provided that full credit, including (C) notice, is given to the source. 
Technical Change and the Relative Demand for Skilled Labor: The United States in Historical Perspective

Lawrence F. Katz and Robert A. Margo

NBER Working Paper No. 18752

February 2013

JEL No. J23,N11,N12

\begin{abstract}
This paper examines shifts over time in the relative demand for skilled labor in the United States. Although de-skilling in the conventional sense did occur overall in nineteenth century manufacturing, a more nuanced picture is that occupations "hollowed out": the share of "middle-skill" jobs - artisans - declined while those of "high-skill" - white collar, non-production workers - and "low-skill" - operatives and laborers increased. De-skilling did not occur in the aggregate economy; rather, the aggregate shares of low skill jobs decreased, middle skill jobs remained steady, and high skill jobs expanded from 1850 to the early twentieth century. The pattern of monotonic skill upgrading continued through much of the twentieth century until the recent "polarization" of labor demand since the late 1980s. New archival evidence on wages suggests that the demand for high skill (white collar) workers grew more rapidly than the supply starting well before the Civil War.
\end{abstract}

Lawrence F. Katz

Department of Economics

Harvard University

Cambridge, MA 02138

and NBER

lkatz@harvard.edu

Robert A. Margo

Department of Economics

Boston University

270 Bay State Road

Boston, MA 02215

and NBER

margora@bu.edu 


\section{Introduction}

Skill-biased technical change has been a pervasive feature of the twentieth century American economy (Goldin and Katz 2008). At the ground level, technical change is frequently embodied in new capital goods, whose price relative to output or labor becomes cheaper over time. As the relative price of capital declines, more capital per worker is used, and capital "deepening" occurs. In the twentieth century, physical capital and skill have been shown to be relative complements so that capital deepening has increased the demand for skilled relative to unskilled labor (Griliches 1969). Technology-skill complementarity has also been widespread over the past century with new technologies from those associated with the electricity revolution in the early twentieth century to the computer revolution in late twentieth century being relative complements with human capital (Goldin and Katz 1998; Autor, Katz, and Krueger 1998). Goldin and Katz (2008, p. 297, Table 8.1), using educational attainment as a proxy for skill, show the growth in the demand for skilled labor greatly outpaced that for unskilled labor in every decade of the twentieth century, with the possible exception of the 1940 s. $^{1}$

The apparent pervasiveness of complementarities between capital and skilled labor in the twentieth century has naturally led economists and economic historians to ask whether such complementarity has been an inherent feature of technical change since the onset of modern economic growth in the United States, or whether it is a more recent phenomenon. Drawing almost entirely on evidence from manufacturing the conventional wisdom is that

\footnotetext{
${ }^{1}$ The 1940s was the decade of the "Great Compression", during which wage differentials by education and skill declined sharply. A portion of this decline can be attributed to a shift in relative demand in favor of less skilled labor that reflected the impact of World War Two on labor demand in agriculture and manufacturing, sectors that were more intensive in the use of less skilled labor; see Goldin and Margo (1992).
} 
technical change was predominantly "de-skilling" in the nineteenth century - capital and unskilled labor substituted for skilled labor with mechanization (Brown and Phillips 1996; Atack, Bateman, and Margo 2004). ${ }^{2}$ In manufacturing, de-skilling occurred as the factory system began to displace the artisanal shop as the United States began to industrialize in the 1820 s, and it picked up pace as production increasingly mechanized with the adoption of steam power after 1850 (Goldin and Sokoloff 1982; Atack, Bateman, and Margo 2008). However, beginning in the late nineteenth century and continuing into the early twentieth century the familiar modern pattern of capital-skill complementarity emerged. This emergence, according to Goldin and Katz (1998), can be substantially traced to the diffusion of electricity as a source of inanimate power and with the technological shift from traditional factories to continuousprocess and batch production methods in many manufacturing industries. The conventional wisdom, in other words, suggests a discontinuity between the nineteenth and twentieth century in the impact of capital deepening on the relative demand for skilled labor.

In this paper we revisit the issue of the historical evolution of capital-skill complementarity and with it, shifts over time in the relative demand for skilled labor. Our paper makes three points. First, although de-skilling in the conventional sense did occur overall in nineteenth century manufacturing, a more nuanced picture is that the occupation distribution "hollowed out." By hollowing out we mean the share of "middle-skill" jobs -

\footnotetext{
${ }^{2}$ In their computable general equilibrium analysis of long-term trends in inequality, Williamson and Lindert (1980) made the prior assumption that capital and skilled labor were relative complements in nineteenth century manufacturing citing evidence from the twentieth century. Williamson and Lindert purported to find a rise in skilled-unskilled wage premium between 1820 and 1860, which they attributed in part to capital deepening, in line with the complementarity assumption. However, Williamson and Lindert's claim of an antebellum "surge" in wage inequality has been challenged (see Margo 2000) as has their assumption of capital-skill complementarity in manufacturing. It is fair to say that the conventional wisdom among economic historians, as noted in the text, is that capital deepening in nineteenth century manufacturing was de-skilling.
} 
artisans - declined while the shares of "high-skill" - white collar, non-production workers - and "low-skill" - operatives and laborers increased. Second, unlike the pattern observed in manufacturing, de-skilling did not occur in the aggregate economy; rather, the aggregate shares of low skill jobs decreased, middle skill jobs remained steady, and high skill jobs expanded from 1850 to the early twentieth century. It is incorrect, in other words, to infer the pattern of occupational change in the economy at large from that occurring in manufacturing. The pattern of monotonic skill upgrading in the aggregate economy continued through much of the twentieth century until the recent period of hollowing out and "polarization" of labor demand since the late 1980s (Autor, Katz, and Kearney 2008; Autor 2010). Third, new archival evidence on wages suggests that the demand for high skill (white collar) workers grew more rapidly than the supply starting well before the Civil War to the end of the nineteenth century.

Our argument begins with the observation that much technical change in manufacturing in the nineteenth century was embodied in "special purpose, sequentially implemented" machinery (US Bureau of Labor 1899; Hounshell 1984). The machines were "special purpose" because they were designed to accomplish specific production tasks that had previously been performed with hand tools by skilled artisans. These machines were "sequentially implemented" in that a partially finished good would be operated on by one machine, followed by another, until the production process was completed or nearly so. Over time, such machines became much cheaper relative to output or skilled labor, and manufacturing became much more capital intensive as a result. 
Although special purpose, sequentially implemented machinery displaced artisans from certain tasks in production, the machines could not run on their own -- they required "operatives." Operatives were less skilled than the artisans they displaced in the sense that an artisan could fashion a product from start to finish, while the operative could perform a smaller set of tasks aided by machinery. ${ }^{3} \quad$ But operatives were not without skills - rather, it is more accurate to say that the skills they acquired were those necessary to operate productively the machinery to which they were assigned (Bessen 2012). Further, skilled workers (engineers and mechanics) were still needed to install and maintain the equipment, as well as design it (and assist in its manufacture) in the first place (Goldin and Katz 1998).

As Adam Smith famously described, the substitution of machines for skilled artisans in manufacturing production raised labor productivity through pure division of labor alone. However, the effects on productivity through division of labor appear to have been relatively modest and exhausted at fairly low levels of output (Sokoloff 1984, 1986). Much larger effects on productivity could be had, however, if the machinery could be powered inanimately, particularly if steam was the energy source. Furthermore, the productivity gains were increasing in firm size, thereby enhancing the division of labor (Atack, Bateman, and Margo 2008). ${ }^{4}$

\footnotetext{
${ }^{3}$ In referring to operatives as less "skilled" than artisans we are following tradition in economic history although it is more accurate to say that the skills acquired by operatives were those necessary to operate the machinery to which they were assigned. While such skills could be acquired fairly quickly, at least compared with the standard apprenticeship in the artisanal shop, they were by no means insubstantial in an absolute sense.

${ }^{4} \mathrm{~A}$ variety of factors contributed to the growth in establishment size in manufacturing, including the transportation revolution (Atack, Haines, and Margo 2011), growth in the supply of less-skilled labor through immigration (Rosenbloom 2002), development of financial markets (Rosseau and Sylla 2005), and legal changes in business organization (Lamoreaux 2006; Hilt 2008).
} 
If the displacement of artisans from production tasks was the dominant effect of capital deepening in manufacturing, the shift towards mechanized factory production would be associated with a reduction in the share of artisans in the manufacturing labor force. ${ }^{5}$ However, as the establishments became larger in size and served geographically expended markets, managerial tasks increased in number and complexity (Chandler 1977). As noted earlier, a more refined portrait of change is that the manufacturing labor force in the nineteenth century "hollowed out" - a decline of "middle-skill" artisan jobs in favor of high and low skill jobs at edges - white collar, non-production workers and less skilled operatives.

The conventional view draws its evidence on de-skilling from manufacturing. However, while manufacturing was a growing share of GNP in the nineteenth century, it was (very) far from the whole economy. The United States experienced a substantial shift of labor out of agriculture during the nineteenth century. Even if the share of operatives was increasing due to organizational change within manufacturing and overall manufacturing growth, it does not follow that the share of unskilled labor was rising in the aggregate economy, because some of the growth in the share of operatives may have come at the expense of a decrease in the share of workers employed as low-skilled farm laborers in agriculture. But farm operators arguably, a middle skill job like artisan - were also in relative decline due to the growth of the non-farm economy, and the overall share of white collar jobs was boosted by the growth of the service sector. The net effect of these shifts on the aggregate relative demand for skill is unclear a priori and cannot be intuited from shifts occurring in manufacturing alone.

\footnotetext{
${ }^{5}$ We should note that in making this statement we are abstracting from the diversity of skills that may have evolved in the artisan labor force as factory production spread; see Scranton (1999).
} 
We use a variety of historical micro data sets to document the narrative just sketched.

Using establishment level data from the $1850-80$ censuses of manufacturing (Atack and Bateman 1999), we examine the relationship between de-skilling and establishment size, building on previous work by Sokoloff $(1982,1984)$, Goldin and Sokoloff (1982), and Atack, Bateman, and Margo (2004). We find that capital deepening was greater in larger than in smaller firms. Much of this difference is attributable to the diffusion of steam power, which was positively correlated with establishment size (Atack, Bateman, and Margo 2008).

Next, we use the manufacturing samples to study the relationships between establishment size, inanimate power, capital intensity, and the various proxies for the relative use of unskilled labor.. When we do not control for establishment size, we observe positive relationships between steam power, capital intensity and the relative use of unskilled labor.. The positive correlations largely disappear, however, when we control for establishment size which is positively related to the percent unskilled, similar to Goldin and Sokoloff's findings for the first half of the nineteenth century (Goldin and Sokoloff 1982). We make use of information on occupation and on imputed industry of employment in the 1850-1900 IPUMS samples to further examine employment changes by skill in manufacturing. ${ }^{6}$ We construct broad occupation distributions for manufacturing at the national level. These distributions go beyond the labor force definition used by the IPUMS (only covering those ages 16 and over) to include child labor (ages 10-15), which was an important component of the nineteenth century manufacturing labor force (Goldin and Sokoloff 1982). The manufacturing distributions exhibit

\footnotetext{
${ }^{6}$ The pre-1910 population censuses recorded occupation but not industry directly. However, the census manuscripts contain sufficient information for the IPUMS staff to impute industry. While arguably less reliable than the actual information reported in 1910 and subsequently, we believe that the imputed data are sufficiently reliable to distinguish manufacturing broadly from other sectors; see Appendix $B$.
} 
hollowing out between 1850 and 1910 - a declining share of skilled artisans, and rising shares of operatives and white collar workers. Next, we use the IPUMS as a base to construct more detailed occupation distributions for the overall economy between 1850 and 1910. The distributions for the aggregate economy show a decrease in the share of unskilled labor, a rise in the percent high skill (professional, technical, and managerial workers), and - unlike manufacturing - comparative stability in the share of skilled artisans and the overall share of middle skill workers (skilled artisans plus clerical and sales workers plus farm operators).

The occupation distributions provide evidence on the quantity side of labor demand versus supply, but to fully interpret the trends they need to be compared to time series of wages by occupation. Building on previous work by Margo (2000) we provide new archivalbased, annual estimates of wages for common labor, skilled artisans, and white collar workers, for the 1820-80 period. We find a secular rise in the premium for white collar workers from 1820 to 1880 . The new wage series suggest that the relative demand for white collar workers outpaced the relative supply over the nineteenth century, unlike the opposite pattern observed during the "high school movement" of the early twentieth century but similar to the pattern observed in the late twentieth century (Goldin and Katz 2008).

In the final section of the paper we examine changes in the occupational distribution of employment from 1920 to 2010 to compare recent changes with those occurring in the nineteenth century. The employment share of high skill occupations (professional, technical and managerial) has increased steadily from 1850 to the present. Monotonic skill upgrading is apparent over most of the twentieth century. The occupational distributions in the aggregate 
economy and manufacturing since 1990 exhibit a hollowing out with a decline in middle skill relative to lower skill jobs. The recent decline in the employment and earnings in middle skill occupations (Autor, Katz, and Kearney 2006; Autor 2010) has a counterpart in the nineteenth century de-skilling of manufacturing. But the modern distributions also suggest, in conjunction with our overall results for the nineteenth century, that relative demand shifts in favor of moreeducated labor can be traced back to at least 1850, and quite possibly even earlier.

There are substantial similarities between our arguments concerning technical change and labor demand shifts by skill in nineteenth century manufacturing with those embedded in the application of recent "task-based" models of computerization and skill-biased technical change to post-1970 changes in the distribution of wages and occupations starting with Autor, Levy, and Murnane (2003). In a task based framework, individuals come to the labor market with a set of pre-market skills, most notably their education. In equilibrium the labor market assigns workers to tasks at a point in time. Over time, technical change alters the assignment of workers to tasks, thereby feeding back on the demand for the underlying skills. In recent years, for example, there has been dramatic erosion in demand for workers in middle-skill white collar work, as these tasks can now be more cheaply undertaken by computer-based technologies which also facilitate international outsourcing. However, while the demand for middle-skill jobs has eroded, the demand for those with higher levels of skills - for example, those who can design and market new software applications or invent more powerful algorithms or design faster computer chips - has increased. Task-based models demonstrate that technical change need not be uniformly skill-biased but rather can be complementary with 
skills in some tasks while substituting for skills in other tasks (e.g., Autor, Katz, and Kearney 2006; Acemoglu and Autor 2010, 2012; Autor and Dorn 2012; Autor 2013).

A task-based framework illuminates an essential continuity to the effects of technical change across the two centuries. In both centuries, the diffusion of new capital goods altered the assignment of workers to tasks. Some of these reallocations displaced skilled labor, while others did the opposite. On net in both centuries, technical change has tended to increase the relative demand for educated labor. The demand side of the "race" between technology and education as described by Goldin and Katz (2008) for the twentieth century has its roots much earlier in American history, perhaps as far back as early industrialization itself.

\section{Interpreting Historical Complementarities: A Simple Framework}

It is useful to have a simple economic framework to interpret historical relationships between technology and skills. The framework we present here is a modest elaboration of Goldin and Katz (1998) in which we consider how the various steps, or tasks, performed in manufacturing production by skilled or unskilled workers were affected by technical and organizational change.

As in the original Goldin-Katz (1998) framework, we assume that there are three technological regimes in manufacturing: the "artisanal shop" (regime \#1), the "factory" (regime \#2), and "continuous processing" (regime \#3). We focus on the transition from the first to second regime, with some discussion on the transition to the third regime. 
We begin by restating the original Goldin-Katz framework. There are two tasks to be performed. In the first task, skilled labor $\left(L_{s}\right)$ is combined with "raw" capital $\left(K_{r}\right)$ to construct an intermediate input called "operating" capital $\left(\mathrm{K}_{\mathrm{o}}\right)$. In the artisanal shop, most operating capital will be partially completed goods - the artisan will be directly involved in making the good, even if he does not put on the finishing touches. However, in the factory, operating capital will be installed machines rather than partially finished goods. In the factory, artisans focus their energies and talents on the machinery used by operatives in task \#2.

In the second production task, operating capital $\left(\mathrm{K}_{\mathrm{o}}\right)$ is combined with unskilled labor $\left(L_{u}\right)$ to produce a finished good $(Q)$. In the artisanal shop unskilled labor puts on the finishing touches whereas in the factory, unskilled labor operates the machinery that fashions the finished product. It is convenient, although not absolutely necessary (Goldin and Katz 1998, p. 700) to assume that the production process for operating capital follows a very simple fixed proportions technology, namely $\mathrm{K}_{\mathrm{o}}=\min \left(\mathrm{L}_{s} / \alpha, \mathrm{K}_{\mathrm{r}}\right)$. Although the fixed proportions technology rules out input substitution in task \#1, Goldin and Katz permit such substitution in task \#2 (for example, with a Cobb-Douglas production function).

Following Goldin and Katz (1998) we assume that inputs are chosen efficiently in task \#2. ${ }^{7}$ Thus, in particular, the desired ratio of unskilled labor to operating capital that will be a (positive) function $(\phi)$ of the ratio of the rental price of operating capital to the unskilled wage

\footnotetext{
${ }^{7}$ This assumption presumes that some amount of labor is allocated to managing the enterprise. Later in this section we introduce an explicit non-production task, such as management.
} 
$\left(f=r / w_{u}\right)$ and the level of output: $L_{u} / K_{o}=\phi(f, Q){ }^{8}$ Exactly how the ratio of unskilled labor to operating capital changes with respect to output depends on the nature of the production process. For example, if division of labor becomes finer at higher levels of output, $\mathrm{L}_{u} / \mathrm{K}_{\mathrm{o}}$ may increase as $Q$ increases.

Letting $\mathrm{S}$ be the share of skilled labor used by firm, it is straightforward to show that $S=\alpha /(\alpha+\phi)$ in the original Goldin-Katz framework (see Atack, Bateman, and Margo 2004). In the artisanal shop the parameter $\alpha$ will be relatively high because each unit of operating capital is a partially completed unit of output. ${ }^{9}$ The parameter $\phi$ is low in the artisanal shop because there is relatively little to be done by unskilled labor to complete the finished good.

By contrast, we expect $\alpha$ to be low and $\phi$ high in the factory. The parameter $\alpha$ will be low because the factory artisan does not spend time in actual production but rather in installing and maintaining machinery. The parameter $\alpha$ is low, because while the factory would use specialized machinery, the empirical evidence suggests that there would be economies of scale in installation and maintenance. For example, in a sewing machine factory whose operations were examined by the U.S. Bureau of Labor (1899) there were just 3 machinists in a workforce of 57 whose functions were listed as "making dies and keeping machinery in order." They were among the higher paid workers in the plant, earning $\$ 2.50$ per day, compared with just $\$ 3.00$ for the engineer and $\$ 3.50 /$ day for the foreman who oversaw the establishment.

\footnotetext{
${ }^{8}$ There is good historical evidence of capital-labor substitution for the nineteenth century United States. Manufacturing in the South after the Civil War became much less capital intensive as interest rates (a component of the rental price of capital) rose relative to the wages of unskilled labor (Hutchinson and Margo 2006).

${ }^{9}$ A complementary explanation is that artisans maintained their own tools in a time-intensive process.
} 
Another critical difference is that factories used higher ratios of unskilled labor to operating capital in the second task, that is, a high value of $\phi$. A higher ratio of unskilled labor per unit of operating capital - the parameter $\phi$ - is the very definition of de-skilling. Factory owners subdivided and simplified tasks so that they could be performed by an unskilled worker working with a specialized machine built for a specific purpose. For example, in the machine manufacture of curved sewing-machine needles, the workers operated automatic cutting machines, cold-swaging machines, pointing machines, a marking machine, grooving machines, clipping machines, burring machines, bending machines, eye-scouring machines, and pointfinishing machines as well as more general purpose machines such as punch presses and polishers and hand tools such as pliers, gauges, and tongs (U.S. Bureau of Labor 1899, pp. 13421343). These highly specialized machines had essentially no uses outside of the specific task for which they were developed (although they could be used in other establishments in the industry operating in the same manner).

In the empirical work presented in the next section we examine the relationship between the use of inanimately powered machinery and skill using establishment level data from 1850 to 1880 . For this period, the key issue is the diffusion of steam power. Measured by horsepower, use of steam in manufacturing increased by nearly sixty-fold from the late 1830s to the late 1870s (Fenichel 1966; Atack, Bateman, and Weiss 1980). In the Goldin-Katz framework, we can think of the use of inanimately powered machinery as affecting the values of both $\alpha$ and $\phi$. Steam engines were fickle beasts requiring specialized expertise to install and maintain (the same was true of water power). The parameter $\alpha$ will be higher in a steampowered establishment compared with a non-powered establishment (Atack, Bateman, and 
Margo 2008). However, there is good evidence that steam power enhanced the division of labor, which would make $\phi$ larger in a steam-powered plant. In addition, steam required coal, and hauling coal on the shop floor (and feeding the steam engines) was performed by unskilled labor, which would also increase the value of $\phi$. If the relative impact of inanimate power is primarily on $\phi$ instead of $\alpha$, we would expect that use of powered machinery would lower the value of S overall in the Goldin-Katz framework. ${ }^{10}$

From the above discussion it follows that share of skilled labor will be higher in the artisanal shop than in the factory. ${ }^{11}$ That is, as manufacturing transitions from the first to the second regime, we expect $\mathrm{S}$ to decline - de-skilling as per the conventional wisdom. De-skilling emerges in the Goldin-Katz framework through increased division of labor as establishments shift the artisanal labor away from production to machine installation and maintenance, and increase the use of unskilled labor per unit of operating capital, which is mostly machinery in the factory unlike in the artisan shop.

Although the original Goldin-Katz framework is well-suited to illuminate the general phenomenon of de-skilling it is not well-suited to examine the possibility of hollowing out. To examine hollowing out it is necessary to distinguish a third task not directly enumerated in the original Goldin-Katz framework - "overhead" or non-production activities. We assume that non-production activities, like those in task \#1, require skilled labor. In particular, we assume

\footnotetext{
${ }^{10}$ This effect operates, however, through division of labor, so if we control of the size of the establishment, we would isolate the impact of power on $\alpha$ which, as noted, is likely to be positive. This is what we find in our empirical work in the next section.

${ }^{11}$ Strictly speaking this prediction should be qualified by the statement "controlling for inanimate power"; however, as discussed in the text, we actually expect that the share of skilled labor will be lower overall in powered establishments if we do not control for establishment size.
} 
that skilled labor used in this third task is in proportion to the amount of unskilled labor used in task \#2: $L_{s 3}=\pi L_{u}$. Here the "3" refers to skilled labor used in task \#3, hence the total amount of skilled labor, $\mathrm{L}_{\mathrm{s}}=\mathrm{L}_{\mathrm{s} 1}+\mathrm{L}_{\mathrm{s} 3}$.

In this slightly modified Goldin-Katz framework it can be shown that $\mathrm{S}$ is given by the following expression:

$$
S=(\alpha+\pi \phi) /(\alpha+(\pi+1) \phi)
$$

We have already claimed that $\phi$ will be lower in the artisanal shop than in the factory and it is likely that $\pi$ is as well. In the artisanal shop the apprentice would work alongside the master, with little in the way of direct supervision. Artisanal shops served limited, local markets, unlike factories which needed sales and (possibly) advertising personnel. Record keeping in the artisanal shop could be quite casual, but the factory needed to keep close track of personnel, raw materials received and used, along with revenues. ${ }^{12}$

In our modified Goldin-Katz framework it is no longer the case that $\mathrm{S}$ will necessarily be lower in the factory than in the artisanal shop, because the non-production effect on skill $(\pi \phi)$ counteracts the direct de-skilling effects through $\alpha$ and $\phi)$. However, a better way to think of the modified framework is that it suggests a more refined way of looking at how the shift from the artisanal shop to the factory altered the relative demand for skills in manufacturing: the

\footnotetext{
${ }^{12}$ The discussion in the text, however, does not do full justice to non-production activities in that it neglects a key difference between the artisanal shop and the factory, namely, the role of product design. In the artisanal shop most products were custom designed by the artisan to fit the needs of the customer. However, the whole point of the so-called "American system" was to create an idealized product - a model - which then could be replicated by operatives using specialized, sequentially implemented machinery in a factory setting. The design process in the factory was clearly subject to increasing returns, unlike the design process in the artisanal shop. The net effect of this shift on skills is not clear, however - fewer custom goods entail less demand for artisans, but model design, not to mention the design and construction of the associated machinery, was a very highly skilled activity.
} 
shift lowered the proportion of skilled artisans, while raising the shares of operatives and nonproduction workers. Following the recent literature on task-based models, we refer to this more nuanced view as "hollowing-out". Instead of limiting attention to the overall share of skilled labor thereby lumping non-production workers and artisans together, the more nuanced view suggests that it is fruitful to distinguish between the two.

We can, in fact, go further than this and think of artisans as a type of "middle" skill worker whereas operatives are unskilled (or low skill) and non-production workers are high skill. ${ }^{13}$ The delineation of skill groups in this manner fits the nineteenth century wage hierarchy reasonably well in which artisans were (much) better paid than common labor but not as well paid generally as white collar workers who performed non-production tasks (Margo 2000). ${ }^{14}$

We have stressed the transition from the artisanal shop to factory regime in this section because the empirical work that follows focuses on this transition. The third regime of continuous processing deserves some brief comment. This third regime differed from the factory in that a higher ratio of capital to unskilled labor was the norm, and electricity was the power source (Devine 1983; Goldin and Katz 1998). The availability of electric power

\footnotetext{
${ }^{13}$ An even more refined framework would allow for different types of skills among non-production workers and the possibility of capital deepening altering the relative demand for such workers. In particular, Rosenthal (2012, ch. 4) documents how the development and diffusion of "ready reckoners" and other mathematical devices permitted less educated workers to perform clerical and accounting tasks that otherwise would have required a highly trained clerk.

${ }^{14}$ Later in the paper we expand the definition of middle and low skill for the nineteenth and early twentieth centuries to include farm operatives, clerical and sales workers (middle) and farm laborers (low). The acquisition of human capital in farming involved the moving up of the "agricultural ladder" from farm laborer to farm operator. This process was not unlike that involved in becoming the owner of an artisanal shop - both were, at the core, small businesses. Although clerks were better paid on average than artisans and the clerk-artisan wage ratio was growing over time (see Margo 2000) the wage gap between the two was not very large absolutely, and clerical and sales jobs can certainly be viewed as middle skill compared with, say, managerial positions. Margo (2000) provides evidence for the antebellum period that, within local labor markets (e.g. counties) wages of farm laborers and common non-farm laborers were essentially equalized.
} 
dramatically altered the architecture of manufacturing plants eliminating a whole category of unskilled jobs involving the movement of bulky raw materials and product from one place to another in the plant. Use of electricity was associated with a substantial increase in the demand for skills acquired in formal schooling, even for blue collar workers, and much higher levels of output, generating new management challenges. The effects of the shift from steam to electricity altered the relationship between size and skill: in the nineteenth century, larger establishments used relatively less skilled labor overall (including non-production workers) but in the twentieth century, skill and establishment size are positively correlated (Brissenden 1929; Davis and Haltiwanger 1991; Goldin and Katz 1998; Atack, Bateman, and Margo 2004).

\section{De-Skilling and Division of Labor in Nineteenth Century Manufacturing: Evidence from the $1850-80$ Censuses of Manufacturing}

Because of limitations of coverage and comparability across the various censuses of manufacturing the full extent of capital deepening in nineteenth century manufacturing is difficult to quantify. However, from 1850 to 1880 for which representative samples of manufacturing firms from the censuses exist, one recent estimate is that capital per worker in manufacturing increased by between 75 to 94 percent, adjusting for changes in the price of capital goods and various biases and omissions in the census data (Atack, Bateman, and Margo 2005, p. 586). The increased intensity in capital usage in manufacturing occurred in tandem with a shift away from artisanal to factory production. Early in the early nineteenth century workers in the typical artisanal shop used relatively limited and non-specific capital goods general purpose hand tools in a workshop that could be used for many different purposes. In 
the factory, tasks were sub-divided and performed by less skilled workers using specialized, sequentially implemented machines (Hounshell 1984). To maximize effectiveness and, sometimes, simply to be used at all, such machines often required more power than could be delivered by human muscle and instead were driven by inanimate sources of energy. Water power had long been used for such purpose, and the eastern United States, where manufacturing first took hold, was blessed by a dense endowment of water power sites (Hunter 1979). Increasingly, after 1850, steam became the power source of choice, displacing and then greatly surpassing water power use. Steam was preferred to water chiefly on grounds of cost and because steam powered establishments could be footloose -they need not be located next to a water power site (Fenichel 1966; Temin 1966; Atack, Bateman, and Weiss 1980; Hunter 1985)..$^{15}$

The shift towards factory production was a proximate cause of capital deepening in manufacturing. Table 1 shows nominal capital-labor ratios computed from the 1850 and 1880 Atack-Bateman manufacturing samples by establishment size. ${ }^{16}$ Adjustments are made to the original data to take account of the possible under-reporting of the entrepreneurial labor input and working capital (Sokoloff 1984; Atack, Bateman, and Margo 2005). The key finding in Table 1 is that, when we control for industry and location, capital deepening was much stronger in larger size establishments than in smaller establishments, particularly those with more than 100

\footnotetext{
${ }^{15}$ For further discussion and general background on the growth of manufacturing in nineteenth century America, see Field (1980), Sokoloff (1982, 1984, 1986), Wright (1990), and Engerman and Sokoloff (2000)

${ }^{16}$ For a detailed discussion of capital data in the nineteenth century manufacturing censuses, see Atack, Bateman, and Margo (2005); the consensus of opinion is that the data refer to market values. Because capital goods prices declined between 1850 and 1880, changes in nominal capital intensity understate capital deepening in the aggregate. We do not deflate by capital goods prices in Table 1 because the currently available price deflator (see Atack, Bateman, and Margo 2005) does not distinguish by size class of establishment. The 1880 figures in Table 1 are re-weighted to take account of the under-reporting of so-called "special agent" industries; see below and Atack, Bateman, and Margo (2005).
} 
workers (see also Atack, Bateman, and Margo 2005, p. 591). ${ }^{17}$ The table also demonstrates that, over time, the manufacturing labor force shifted away from small establishments to large establishments - that is, the artisanal shop was displaced by the factory. Not only were more workers employed in factories in 1880 than in 1850, capital deepening was disproportionately concentrated in factories rather than in artisanal shops.

The primary reason why capital deepening was more extensive in larger than in smaller firms after 1850 was the diffusion of steam power was not neutral with respect to establishment size. Traditional accounts of the diffusion of steam in American economic history emphasize decreases in in the user costs of steam compared with water power and also the geographic spread of markets for coal, which was facilitated by the transportation revolution (Atack 1979; Atack, Bateman, and Weiss 1980). While these features of the diffusion of steam power are certainly important, the traditional account misses the critical role played by establishment size - larger establishments were more likely to use steam than smaller establishments. The size-steam pattern is evident as early as 1850 and, moreover, becomes steeper over time because changes in steam use were disproportionately concentrated in larger establishments (Atack, Bateman, and Margo 2008). A primary reason why diffusion of steam was concentrated in larger establishments is that the labor productivity

\footnotetext{
${ }^{17}$ Table 2 of Atack, Bateman and Margo (2005, p. 591) shows that factories (those with 16 or more workers) were more capital intensive in 1880 than non-factories, but does not present the contrast with 1850, as does Table 1 in the present paper.
} 
gains from steam were increasing in establishment size, relative to water power or pure division of labor alone (Atack, Bateman and Margo 2008). ${ }^{18}$

We would like to be able to explore how the shift to capital-intensive, steam-power production affected the allocation of tasks in nineteenth century manufacturing. The prevailing hypothesis, as discussed earlier, is that mechanization-cum-capital deepening promoted the substitution of operatives for skilled artisans. In steam powered establishments artisans were less involved in the production process from start to finish - rather, they were needed primarily to install and maintain the machinery. But the establishments were also larger in size, which entailed new and more complex managerial responsibilities. In small establishments the shop owner - the master artisan - would undertake managerial tasks but in larger establishments these too, were subject to division of labor. As long as the extent of division of labor of managerial tasks was less than that in installation and maintenance of equipment, however, we should observe that the percent operative should be higher in steam powered, capital-intensive establishments, when other factors are held constant

For the twentieth century there are a variety of data that can be used to shed light on complementarities between skilled labor and capital in manufacturing, as well as the trends in the relative demand for skilled labor in the broader economy (Goldin and Katz 2008). For the nineteenth century, the available data are sparser and any analysis is suggestive rather than definitive. We present two types of (more or less) direct evidence on skill intensity in this

\footnotetext{
${ }^{18}$ Productivity gains are not the only reason why steam power diffused more rapidly among larger establishments. For example, because steam engines were relatively costly, larger establishments also may have been more able to finance their purchase out of retained earnings; see Atack, Bateman, and Margo (2008).
} 
section. ${ }^{19}$ The first, following Goldin and Sokoloff (1982), examines the relative use of female and child labor across different types of manufacturing establishments. The idea is that, on average, female and, especially, child labor was less skilled than adult males, and thus the percent female/child is a proxy for the percent operative. Our second analysis makes use of information that was collected as part of the 1880 Census of Manufactures most of which was never compiled in the published census volumes. In particular, the census asked two questions pertaining to the average daily wages of "common labor" and "mechanics". We explore how the incidence of reporting to these questions varies across establishment characteristics. We also use these data, in conjunction with an estimate of the overall average daily wage, to construct a proxy for the overall percent unskilled.

Economic and social historians have long been aware of the role played by female and child labor in early industrialization, but scholarly understanding was advanced significantly in a celebrated article by Claudia Goldin and Kenneth Sokoloff (1982; see also Goldin and Sokoloff 1984). In contrast to previous work which was anecdotal or focused on particular firms or industries, Goldin and Sokoloff systematically examined census and related micro-data for the first half of the nineteenth century, drawing on the 1820 and 1850 manuscript federal censuses of manufacturing, and the 1832 McLane Report prepared by the U.S. Treasury department.

\footnotetext{
${ }^{19}$ An alternative approach pioneered by Atack, Bateman, and Margo (2004) makes use of indirect evidence on skill intensity as reflected by the average wage at the establishment (the "establishment wage" to use Atack, Bateman, and Margo's terminology). The idea is that, if the percent operative effect dominates, and all other factors affecting skill intensity or wage rates are controlled for, the establishment wage should decrease as establishment size increases. Atack, Bateman, and Margo show that this was the case in both 1850 and 1880; further, the distribution of establishment wages shifted to the left, as the density of employment at larger establishments with lower average wages increased between 1850 and 1880.
} 
Goldin and Sokoloff's principal focus was the relationship between the relative use of female and child labor, as measured by the share of workers who were children or women, and the size of the establishment, as measured by the total number of workers. The key finding was that the percent female or child was positively correlated with establishment size. Importantly, the positive correlation remained even after controlling for the level of urbanization in the country where the firm was located, a New England regional dummy, and industry. These controls are important because they demonstrate that the establishment size pattern was quite general, not driven by particular, well-known examples such as cotton textiles, or local geographic or labor market factors.

Our empirical analyses draw upon the Atack-Bateman manufacturing samples for 185080 (Atack and Bateman, 1999) covering the period of much of the diffusion of steam power in U.S. manufacturing (Fenichel 1966; Atack, Bateman, and Weiss 1980). The power data were only tabulated in the published census starting in 1870 (Atack, Bateman and Weiss, 1980).

The information reported on the labor force varies before and after the Civil War. For 1850 and 1860 the schedules report the number of male and female worker separately whereas for 1870 and 1880 , the data are more detailed - children, females, and males, the latter two for ages 16 and over. Unfortunately, there is no easy way to make these data fully comparable over time. For 1850 and 1860 , we specify the dependent variable to be the percent female; for 1870 and 1880, it is percent of workers who were children or female.

The regressions of child and female employment are shown in Table 2. To be included in the regression samples, establishments had to report positive values of total employment, 
capital invested, gross value of outputs and inputs, and value added (= value of outputs - value of raw materials). In addition, we excluded establishments whose estimated rate of return on capital was either so high or so low to raise questions about the accuracy of the data. The various data screens are the same as used in previous work (see, for example, Atack, Bateman and Margo 2008). The 1880 sample is re-weighted to take account of the under-reporting of so-called "special agent" establishments. ${ }^{20}$

Panel A shows results for $1850-60$ and Panel B for $1870-80$. The structure of the panels is identical. In column 1, we control for inanimate power use-dummy variables for steam and water power and the log of the capital-labor ratio. We expect the power and capital intensity coefficients to be positive in sign, although because power use and capital intensity are positively (and strongly) correlated, they may not be precisely estimated (that is, statistically significant). In column 2, we add the number of workers to the specification. We expect that this variable will have a positive and significant coefficient, and controlling for it should explain the positive effects of capital intensity and power use in column 1, possibly even reversing their signs. The remaining columns either add county fixed effects (columns 3 and 4) or estimate the regressions separately by power source, and are meant as robustness checks.

\footnotetext{
${ }^{20}$ Although the samples analyzed here are nationally representative of the surviving manuscript schedules, they are not necessarily nationally representative of all manufacturing establishments because some establishments were missed and some schedules have not survived. We can presume that these omissions are random except in 1880. In 1880, however, certain industries (including textiles and iron and steel) were assigned to special enumerators chosen for their specialized knowledge about the industry. Their enumerations were not deposited with the other census data and the records have never been found (Delle Donne 1973). Fortunately, not all enumerators followed the instructions and, in fact, there are firms from the special agent industries contained in the regular schedules (and thus included in the Atack-Bateman samples). We use these establishments to construct a set of weights to correct for the under-representation. Although this reweighting is a clear improvement over no adjustment at all, it is unlikely to fully correct for the problem; as a result the 1880 sample, even when re-weighted, has too few large establishments in it. Thus, our substantive findings with respect to size are likely to be understated even when the 1880 data are re-weighted.
} 
There are two key results, which are remarkably consistent across the samples despite the difference before and after the Civil War in the definition of the dependent variable. First, the percent female or female and child is positively and significantly related to the use of steam power. We also generally observe a positive effect of capital intensity, controlling for power, although these are not statistically significant given the multi-collinear relationship between power use and capital intensity.

Second, if we add establishment size to the regression (the number of workers) its coefficient is uniformly positive and significant. The positive effect of size is consistent with Goldin and Sokoloff (1982). Note that, when we control for size, the coefficient on steam power becomes negative. In terms of the Goldin and Katz (1998) framework, steam powered machinery required installation and maintenance and these were tasks for skilled labor, even if semi-skilled operatives or unskilled workers could operate the machinery.

Although compelling, the evidence on size and relative use of female and child labor does not reflect the full extent of division of labor in nineteenth century manufacturing, because many establishments did not hire women or children, and yet were relatively large. Thus additional direct evidence is desirable. Specifically, the 1880 census of manufacturing collected data on the average daily wages of "mechanics" and "ordinary" laborers. Although neither term was defined by explicitly in the instructions to enumerators it is clear from the context that "mechanics" referred to skilled artisans like machinists, blacksmiths, and engineers while ordinary labor meant "common laborer". Except for a few industries these data were 
not compiled in the 1880 census volume on manufacturing, but they are available in the manuscripts and also in the Atack-Bateman 1880 sample (Atack and Bateman 1999).

The instructions to enumerators on collecting the wage data are extremely sparse but one particular instruction is still very useful to us. Referring to the column where the data on the average wage of ordinary laborer was to be recorded, the census noted that "[i]n many establishments (as carpenter shops, blacksmith shops, etc.) it will be found that no ordinary laborers are employed. In this case column 11 will not be filled" (Wright 1900). We infer from this instruction that the wage data were supposed to refer to individuals employed at the establishment, and if no such labor was employed, the column would be left blank.

With this instruction in mind, we created a variable, ART, which equals one if the establishment reported a wage for mechanics but not for ordinary labor. We also created a second variable, BOTH, taking the value one if the establishment reported both types of wages. As can be seen from Table 3, the majority of establishments in 1880 (67 percent) reported both types of wages but a substantial minority, 25 percent, reported just the mechanic's wage. The likelihood of reporting just the mechanic's wage was significantly decreasing in the number of employees, whereas the likelihood of reporting both was increasing in the number of workers. Note, as well, that use of steam power reduced the likelihood that just the skilled wage was reported. These patterns are consistent with the hypothesis that division of labor increased with establishment size and was enhanced by mechanization.

Lastly, we use the information on the reporting of skilled and unskilled wages, total wages paid, the number workers hired, and operating times to construct a proxy for the overall 
share of workers in an establishment who were unskilled. The details of constructing this proxy are given in appendix A. We concede that our proxy is clearly biased, but we believe that the biases go against our finding that the percent operative increased with establishment size (see appendix A). Panel B of Table 3 reports regressions of this proxy on establishment characteristics. We find that, not controlling for establishment size, the proportion unskilled was increasing in the use of steam power and also in capital intensity but, as we found in the analysis of female and child labor, the effect of steam power disappears once we control for establishment size, which is positively associated with the percent unskilled.

In summary, we have used the 1850-80 Atack-Bateman manufacturing samples to shed light on the relationship between steam power, capital intensity, and the percent unskilled. We find, not controlling for size, that steam power and the percent unskilled were positively correlated, as were capital intensity and percent unskilled. Echoing Goldin and Sokoloff (1982) and Atack, Bateman and Margo (2004), we find that larger establishments were more likely than smaller establishments to substitute unskilled labor and capital for skilled labor.

\section{Occupations in Nineteenth Century America: Did Technical Change "Hollow out" the Distribution?}

Our analysis of the manufacturing samples is consistent with the view that technical change in nineteenth century manufacturing displaced artisans from production tasks, replacing them with operatives and machines. We are also interested in whether the occupation distribution in manufacturing hollowed out. However, we cannot investigate 
hollowing out using the 1850-80 manufacturing samples because the census of manufacturing did not separately identify non-production workers until 1890.

At first glance, it might also seem that hollowing out cannot be investigated using information collected in the census of population, either. From 1910 onward the census collected information separately on each worker's occupation and industry, but prior to 1910 industry of employment was not separately recorded. However, sufficient information was reported in the manuscripts to permit the construction of protocols by the IPUMS to impute industry of employment prior to $1910 .{ }^{21}$ This is because in answering the occupation question, individuals also gave information sufficient to identify the industry of employment. And, even if this did not happen explicitly, industry can in many cases be inferred directly from the occupation. Importantly, when imputing industry, the protocols used by the IPUMS staff do not have our question of interest in mind - that is, they did not impute industry with the conscious desire to show hollowing-out in the manufacturing distribution.

We have scrutinized the IPUMS protocols for assigning industry and believe them to be reasonable. Although there is no question that the imputed industry codes are less accurate than their twentieth century counterparts, we believe they are adequate for the type of broad analysis undertaken here - distinguishing "manufacturing" overall from other sectors. ${ }^{22}$

Appendix B describes our procedures for computing the occupation distributions. Our goal is to make the coverage of the distributions as comprehensive as possible - that is, the

\footnotetext{
${ }^{21}$ See IPUMS-USA (undated) for a detailed discussion of the protocols.

${ }^{22}$ We are less sanguine that the imputed industry data are sufficiently accurate to analyze differences in hollowing out across manufacturing industries. That said, there are any number of interesting hypotheses to could be tested - for example, we might expect more hollowing out to have occurred in manufacturing industries with broader, more geographically integrated markets because these may have required larger clerical/sales labor forces.
} 
entire labor force, as opposed to a specific subgroup. ${ }^{23}$ In brief, we begin with the IPUMS samples, which pertain to persons in the labor force, ages 16 and over. To these we add estimates for child workers, ages 10-15, and we also make a series of technical adjustments which we believe produce more accurate occupational classifications. Because we rely on the IPUMS for the basic estimates, we cannot provide distributions for 1890 (there is no IPUMS sample for 1890).

Panel A of Table 4 shows our estimates of occupations in manufacturing, distinguishing between white collar (profession/technical/manager and clerical/sales), skilled blue collar (that is, artisan), and operative/unskilled. Even as early as 1850, almost 60 percent of manufacturing workers are classified as operative or unskilled. This is perhaps less surprising as it might seem, however - the shift away from the artisan shop was well underway even before steam power diffused (Goldin and Sokoloff 1982; Sokoloff 1984; Atack, Bateman, and Margo 2008). We cannot, however, document the pre-1850 transition precisely, however, because the pre-1850 censuses did not report occupations in sufficient detail.

That said, consistent with the results of the previous section there is clear evidence of "de-skilling" in the traditional labor history sense in Panel A: the proportion artisan in manufacturing declines from 39 percent in 1850 to 23 percent in 1910 . The decline is

\footnotetext{
${ }^{23}$ We want the distributions to be comprehensive because historically the labor force included groups - child labor and slaves, in particular - whose occupations were not recorded at all in the population census (for example, slaves) or who were incompletely enumerated (children). For example, if we failed to include slaves in the antebellum distributions, emancipation would be associated with a shift in the occupation distribution (a sudden increase in the share of unskilled labor) that reflects the fact that the occupations of former slaves were enumerated in 1870, but not in 1860 . On the other hand, comprehensiveness is not without cost because the adjustments that we make for slave and child occupations are necessarily crude, and also because at present the wage series that we present later in the paper is not as comprehensive in its coverage (see the discussion in the next section).
} 
continuous, although it did not occur at the same rate across decades - the downward shifts in percent blue collar were more dramatic during the 1860 s and between 1900 and 1910 . The flip side of de-skilling, of course, is the rise in the percent operative/unskilled, from 58 percent in 1850 to 65 percent in 1910. But de-skilling is not the full story - we also observe an upward trend in the percent white collar from 3 percent in 1850 to almost 12 percent in 1910. Prior to 1880 most of this growth was concentrated among managers rather than clerical or sales workers, whose proportion began to grow rapidly in the late nineteenth century.

Our evidence suggests, therefore, that the occupation distribution in manufacturing hollowed-out between 1850 and 1910 . The hollowing out is clearly evident if we consider "high skill" jobs in manufacturing to be all white collar jobs, or even if we follow the definition of middle skill used later in the paper in our analysis of twentieth century trends, treating clericalsales positions as "middle skill", along with skilled blue collar.

Did the hollowing out extend beyond manufacturing? We address this question in panels $B$ and $C$ by presenting occupation distributions for the aggregate economy. As for manufacturing we construct the overall distributions by starting with samples drawn from the IPUMS. To these initial distributions we add child labor, slaves (1850 and 1860) and also make a series of technical adjustments (see appendix B).

In Panel C, we re-arrange the occupation shares into skill groups: high skill 1 (white collar workers), middle skill 1 (the sum of skilled blue collar and farm operators), and low skill (the sum of operative-service-unskilled in non-farm jobs and farm laborers). Following the classification in Panel A (as also used later in the paper) we also present results in which the 
high skill group is limited to professional/technical/managerial and the middle skill group is expanded to include clerical/sales. These skills groups correspond (roughly) to their average position in the wage distribution for the nineteenth century and, we believe, in the distribution of schooling at the time although we lack detailed data to verify this.

The hollowing out evident in manufacturing does not extend to the position of artisans in the overall economy, at least after 1850. As shown in Panel A, there is a modest decline in the percent skilled blue collar from 12 percent in 1850 to 9 percent in 1880, which is subsequently reversed such that the artisan share in 1910 is slightly higher than in 1850. Although the artisan share declines in manufacturing, the employment of artisans was relatively high in manufacturing compared with other sectors, and the percent manufacturing grew after 1850. The economy also became more urban over time which fueled the growth of the construction industry, which was also relatively intensive in the use of artisan labor.

Our second finding is that, in the aggregate economy, the share of high skill workers, whether defined narrowly (professional/technical/manager) or more broadly (all white collar) rose monotonically from 1850 to 1910, while the share of low skill jobs fell. The share of low skill jobs fell entirely because the share of farm laborers declined to more than offset the rise in the share of operatives, unskilled labor, and service workers in the non-farm economy.

Note that when we define the middle skill group to be artisans plus farm operators, this share also falls over time, absolutely and relative to the low skill group. ${ }^{24}$ In other words, between 1850 and 1910 there was relatively more growth in high skill jobs and relatively less

\footnotetext{
${ }^{24}$ The ratio of the middle to lower skill group was 0.55 in 1910, compared with 0.62 in 1850 . The decline in the relative share took place after 1870 .
} 
decline in low skill jobs, compared with middle skill jobs - a type of hollowing out, although nowhere near as dramatic as occurred in manufacturing proper. But if one moves clerical and sales workers into the middle skill group, then there is substantial stability in the middle skill share from 1850 to 1910 . Perhaps the most important point, however, is that absolute and relative growth occurred in white collar occupations between 1850 and $1910 .^{25}$ Because the nineteenth century censuses did not record educational attainment we cannot directly measure the schooling levels by occupation in the nineteenth century. However, from abundant descriptions of such jobs and workers, white collar workers were better educated than the average, and they routinely used literacy, numeracy, and related skills acquired in formal schooling to a greater extent than was true of artisans, operatives, or common laborers. ${ }^{26}$

\section{Occupational Wage Differentials in the Nineteenth Century: Supply or Demand?}

We have shown that the share of white collar workers in manufacturing increased from 1850 to 1910 , while the share of skilled artisans decreased and that of operatives increased. In the aggregate economy the share of artisans was stable while the share of unskilled labor fell, but the white collar share followed the same upward trend as it did in manufacturing.

Our story about capital deepening and firm size is a labor demand-side explanation of the occupation trends in manufacturing. We have not tried to claim that the story in its particulars is relevant outside of manufacturing but it would be easy to point to technological

\footnotetext{
${ }^{25}$ See Rosenthal (2012, Figure 4.4, p. 170) for additional evidence on the growth of white collar workers from 1850 to 1900. In particular, Rosenthal uses the original occupational "strings" (that is, the text) to compute the number of clerical and accounting workers per 100,000 people. Her series increases from approximately 550 such workers per 100,000 in 1850 to approximately 1,200 per 100,000 people in 1900.

${ }^{26}$ Goldin and Katz $(2000,2008)$ directly document using the lowa State Census of 1915 that white collar workers had much higher levels of formal schooling than other workers in the early twentieth century.
} 
change outside of manufacturing that could have increased the relative demand for white collar workers. For example, the transportation revolution fueled growth in the service sector as well as urbanization, and as a byproduct increased the demand for white collar workers (Haines and Margo, 2008; Atack, Haines, and Margo 2011).

The occupation distributions in the previous section refer to quantities, and we cannot conclude from these alone that shifts in labor demand were responsible for the relative growth in white collar workers. In particular, school enrollment rates and educational attainment were increasing over time. To distinguish between demand and supply explanations, we need information on wages.

Previous work by Margo (2000) and by Goldin and Katz (2008) gives some insight into this issue. Margo (2000) provides annual wage series for common labor, artisans, and white collar workers from 1821 to 1860, while Goldin and Katz (2008) provide benchmark estimates of wage ratios - for example, white collar to operatives - for the late nineteenth and early twentieth century. According to Margo's time series, the white collar-common labor wage ratio increased from 1820 to 1860, and Goldin and Katz's benchmark estimate of this wage ratio for the late nineteenth century is higher than Margo's estimate for the late antebellum period. By contrast, Margo finds a slight decline in the artisan/common labor wage ratio from 1820 to 1860 , and Goldin and Katz's benchmark for this wage ratio in the late nineteenth century is similar to Margo's estimate ca. 1860. These results suggest that the relative demand for artisans (net of relative supply growth) was quite stable over the nineteenth century, while the relative demand for white collar labor increased rapidly given increasing 
educational attainment levels. But the precise time path of relative wages in these

occupations between 1860 and Goldin and Katz's benchmarks is not known.

In this section, we provide some additional evidence on occupational wage differentials for the nineteenth century. This evidence draws on the same source used by Margo for his antebellum series, namely the so-called Reports of Persons and Articles Hired for army forts in the nineteenth century. ${ }^{27}$ The data specifically analyzed here pertains to the period 1866 to 1880 , and is used to generate national aggregate series of daily wages for common labor and artisans, and monthly wages for white collar workers, analogous to the series previously published by Margo for the antebellum period. ${ }^{28}$ The data set contains approximately 17,000 wage observations (the unit of observation is a person-month).

Following Margo (2000), hedonic wage regressions are estimated for unskilled labor, artisans, and white collar workers. Separate regressions by census region (Northeast, Midwest, South Atlantic, and South Central) are estimated for artisans and unskilled labor, but the sample sizes are such that only a national regression can be estimated for white collar workers. The dependent variable is the log of the daily (or monthly) wage. The independent variables

\footnotetext{
${ }^{27}$ Margo (2000, ch. 2) provides extensive evidence to show that that wages at the forts were very similar to those in the purely civilian economy in the local labor market. This evidence pertains to the antebellum period but there is no reason to suppose that the patterns would be different for later in the century. That said, we recognize that the forts differed substantially as economic organizations from manufacturing and other types of firms in the civilian economy and for all sorts of reasons the workers at the forts could differ from those in the civilian economy, and consequently cause the trends in wages at the forts to deviate. We think that any such bias is likely to be minimal for the common labor wage series because of the extensive benchmarking, but we cannot make the same claim for the artisan or white collar series.

${ }^{28}$ Thus far no data have been collected for the Civil War years (1861-65). Although such data are available for some forts, a separate study is necessary to determine their usefulness for capturing trends in the civilian economy.
} 
include dummy variables for separate occupations (for example, mason), the month of the year, the pay period (for example, monthly versus daily), fort (or state), and year.

The series for common labor are extensively benchmarked at the regional level. ${ }^{29}$ The series for artisans and white collar workers, unfortunately, cannot be so extensively benchmarked. Instead, a national average wage for artisans and white collar workers is computed using census data for $1880 .^{30}$ As far as possible, the benchmarking is done so as to produce a consistent series with those previously published by Margo (2000). Once the benchmarks are available, it is straightforward to use the coefficients of the time dummies to generate nominal wage series. Further details of the construction of the wage series can be found in Appendix C.

Although the new wage series are, in our opinion, superior to any previously available, they have important limitations that should be kept in mind. First and foremost, the series at present pertain to narrow slices of the labor force - (free) white males whose skill levels are judged to be typical (or modal) for their occupation. Thus, for example, the series for artisans pertains to those of average skill - not, say, master carpenters or apprentice masons. This limitation is important because the occupation distributions presented in the previous section are more comprehensive in coverage than the wage series. Whether this affects our substantive conclusions is difficult to say although our operative belief is that any bias is small. ${ }^{31}$

\footnotetext{
${ }^{29}$ The regional series were published in summary form (e.g. five year averages) in Margo (2004) and the annual series are available in Margo (2002).

${ }^{30}$ The 1880 wage data come from the so-called Weeks report. The white collar data from Weeks are chosen to reflect the tasks performed by white collar workers at the forts - standard clerical and bookkeeping skills that were also in widespread use in the purely civilian economy.

${ }^{31}$ The principal issue is the inclusion of child and female labor, and slaves before the Civil War, in the wage series. Margo's (2000) antebellum regressions do control for slave status for forts located in the South, but the number of
} 
Second, while the skills demanded at the forts were in widespread use in the general economy the economic organization of the forts was not the same as, say, the typical manufacturing establishment. On the other hand, there is good evidence that wages at the forts were sensitive to local economic conditions and, in general, were very similar to what the workers would have commanded in the purely civilian economy (Margo 2000).

Panel A of Table 5 shows five year and decadal averages of the full (1820-1880) series along with estimates of the coefficients of linear time trends. Panel B shows wage ratios based on the decadal averages in panel A. Looking first at the wages of skilled artisans relative to common labor, we observe a shallow $U$ shaped pattern - a decrease in the relative wage of skilled artisans before the Civil War followed by a modest rise in the 1870 s. Overall, however, there is no secular trend in the wages of skilled artisans relative to common labor. The occupation distribution for the overall economy in Table 4 also follows a shallow $U$ pattern but is probably better summarized by saying there was little overall trend in the relative shares of skilled artisans versus unskilled labor (see panel C of Table 4).

For white collar labor there is an upward trend in relative wages over the 1820 to 1880 period, which coincides with the upward trend in the percent white collar in the overall economy. It follows that the relative demand for white collar workers increased compared with relative supply over this time period. The extent to which relative demand grew faster

observations on slaves is insufficient to estimate separate wage series. Female and child workers were paid much less than adult white males, and including these workers in the series would reduce the level of the common labor wage series, thereby increasing the level of the skill premium for artisanal and white collar workers. Goldin and Sokoloff (1982) present evidence that the wages of child and female workers in manufacturing increased relative to adult men between 1820 and 1850; this suggests, for example, that a more comprehensive series might show a smaller increase in the ratio of wages of white collar to common labor before the Civil War and perhaps a larger decline in the ratio of wages of skilled artisans to common labor. 
than relative supply seems to have been modest, however, since the relative wages of clerical workers compared with common labor were approximately 10 percent higher ca. 1880 than in 1850, whereas the share of white collar workers in the economy more than doubled. ${ }^{32}$ To the extent that the gap in the educational skills embodied in the typical white collar worker relative to other workers remained reasonably stable over the course of the nineteenth century, the rise in the white collar wage premium also suggests that the relative demand for educated labor increased faster the relative supply of educated labor. Goldin and Katz (2008) provide extensive documentation that the relative demand for educated labor increased throughout the twentieth century. Our results suggest that these increases began rather earlier in American history, at least as far back as the middle of the nineteenth century. Although the census does not allow us to trace occupation distributions prior to 1850 , it is almost certainly the case that the share of white collar workers in 1820 was lower than the share in 1850 . Since the increase in relative wages of white collar workers appears to begin in the 1820 s, the increase in relative demand for educated workers probably began with the onset of industrialization in the United States.

\section{Technical Change and Occupations in the Twentieth Century}

Skill-biased technical change from electrification in the early twentieth century to computerization in recent decades has driven a rapid secular growth in the relative demand for more-educated workers. But the supply of skills at least kept pace with the demand for skills over most of the twentieth century (Goldin and Katz 2008). Growth in the supply of skills was

\footnotetext{
${ }^{32}$ See Rosenthal (2012, Chapter 4) for evidence that a wide variety of educational institutions emerged after 1850 to meet the growing demand for clerical, accounting, and related skills.
} 
largely due to the increased educational attainment of successive cohorts fueled by increased access to public high schools in the early twentieth century and later to colleges and universities. The upshot of these factors was the educational wage differentials narrowed from 1915 to 1980.

But U.S. educational wage differentials and overall wage inequality have increased sharply since 1980. Goldin and Katz (2008) show that a slowdown in the growth of the supply of skills of the U.S. working population combined with continued growth in the relative demand for skills can substantially explain the recent increase in educational wage differentials.

The rate of growth of the relative demand for more-skilled workers does not seem to have accelerated since 1980, but there is much evidence that changes in skill demand have shifted since the 1980s from being monotonically rising in skill to a polarization of labor demand that is U-shaped in skill favoring high-wage jobs and lower-wage in-person service jobs relative to middle-skill jobs. This pattern of skill demand shifts is consistent with a shift from the monotonic widening of the U.S. wage structure in the 1980s to the divergence of upper-half and lower-half wage inequality since the late 1980s with upper-half wage inequality continuing to increase and lower-half wage inequality growth (if anything) slightly reversing in the 1990s (Goldin and Katz 2007; Autor, Katz, and Kearney 2008; Autor 2010).

Changes in the organization of work associated with computerization raise the demand for the cognitive and interpersonal skills used by highly-educated professionals and managers and reduce the demand for the routine analytical (non-manual) and mechanical (manual) skills that characterize many middle-educated ordinary white-collar positions and manufacturing 
production jobs. Computerization has less direct impact on the demand for non-routine manual skills in many low-wage in-person service jobs and in the building trades (Autor, Levy, and Murnane 2003, Autor, Katz, and Kearney 2006; Acemoglu and Autor 2010; Goos, Manning, and Salomons 2011).

We next examine changes in the occupational distribution of employment from 1920 to 2010 in Table 6 to gain insights into the post-1980 pattern of skill demand changes relative to those over much of the twentieth century and those in the second-half of the nineteenth century (shown earlier in Table 4). We focus on the occupations of individuals employed in the civilian work force aged 16 or older using the IPUMS micro data for the 1920 to 2000 decadal Censuses of Population and the 2010 American Community Survey (ACS). Occupations are classified into occupational groupings using 1950 Census occupation codes and the consistent coding of each Census and ACS year's occupation codes into the 1950 codes by the IPUMS.

Panel A of Table 6 displays changes in the occupation distribution for the aggregate civilian economy from 1920 to 2010. We focus on a categorization of occupations based on recent rankings by education and wages into High Skill (professional, technical, and managerial occupations that increasingly require at least bachelors' degree), Middle Skill (clerical, sales, skilled blue collar, and farm operators), and Low Skill (operatives, laborers, farm laborers, and service occupations). The employment share of high skill workers (as well as of the overall white collar work force) secularly increased from 1920 to 2010 continuing a trend going back at least to 1850 with the High Skill share more than tripling from 12 percent in 1920 to over 39 percent in 2010. Monotonic skill upgrading is seen in the occupational distribution throughout 
most of the twentieth century (through 1980) with the share in High Skill occupations rising, Middle Skill occupations holding steady, and Low Skill occupations declining. The stability of the Middle Skill group from 1920 to 1980 hides a rise the clerical/sales share, stability for skilled blue collar, and a steep decline for farm operators. The declining share of Low Skill employment is driven by farm laborers in the first half of the twentieth century and by operatives and laborers (largely in manufacturing) in the second half of century. In contrast, the share of employment of service workers -- the other low-skill and currently the lowest wage occupational group - increased (almost doubling) from 1920 to 2010 with the most rapid growth in the last decade. Panel B of Table 6 shows a similar pattern of monotonic occupational skill upgrading in manufacturing industries from 1920 to 1980.

A hollowing out of the occupational skill distribution with a declining share of jobs in Middle Skill occupations is apparent both in the aggregate economy and in manufacturing since 1980 and especially from 2000 to 2010 . The High Skill employment share has continued to increase rapidly since 1980 . And the decline the Low Skill employment share has slowed since 1990 with an actual increase in the aggregate Low Skill share from 2000 to 2010 driven by the rapid relative growth of in-person service jobs. More detailed analysis of the full set of threedigit occupations by average education levels and wages in 1980 show a shift from monotonic occupational skill upgrading through the 1980 s to polarization pattern of the upper and lower ends gaining against the middle since 1990 (Autor, Katz, and Kearney 2008; Autor 2010).

The employment share of High Skill occupations that increasingly require at least a college degree has more than tripled since 1920. And the college wage premium after declining 
in the first half of the twentieth century has risen substantially since 1980 back to at least the level prevailing in 1915 in the fact of a growing relative supply of college-educated workers (Goldin and Katz 2008). This pattern indicates strong secular relative demand shifts favoring more-educated labor over the last century. And the evidence on occupation employment shares and relative earnings in the nineteenth century in Tables 4 and 5 indicate that rapid increases in the relative demand for more-educated works dates back at least to 1850 .

Furthermore, the recent period of the hallowing out of middle skill jobs associated with the reorganization of work from computerization in the aggregate economy and manufacturing has parallels to the decline in middle skill artisans in U.S. manufacturing the nineteenth century with the shift from the artisanal shop the factory.

\section{Conclusion}

Technology has been an engine of economic growth in the United States since the onset of industrialization. In the twentieth and twenty-first centuries technology has been skillbiased overall, favoring more-educated labor. But the conventional wisdom among economic historians is that technical change in the nineteenth century may have had the opposite effect de-skilling. The switch to capital-skill complementarity allegedly occurred in the early twentieth century with the diffusion of electricity as an inanimate power source.

In this paper we have revisited the question of the historical evolution of capital-skill and technology-skill complementarity in the United States. In contrast to the conventional wisdom, we have instead stressed the continuity of the effects of technical change on the 
relative demand for skill. It is true, as we document extensively in this paper, that in nineteenth century manufacturing technical change reduced the relative demand for artisans in favor of machines operated by less skilled workers and, in that sense, certainly was de-skilling. But a more nuanced picture shows that the manufacturing workforce hollowed out: in addition to operatives, non-production workers, who on average were more educated, not less, increased their employment shares relative to artisans. And in the aggregate economy of the nineteenth century we find no evidence of de-skilling overall but rather the opposite, as demonstrated by a persistent, long term increase in the share of white collar workers. In the twentieth century technical change has largely had a monotonic effect on the relative demand for skill until quite recently. But the occupation distribution has again hollowed out since the 1980s. Drawing on the recent literature on task-based models (Acemoglu and Autor 2010), we argue that there is a common theme to the effects of technical change across the two centuries, displacing skilled labor from some tasks, but increasing its use in other tasks.

We have stressed the effects of technical change on the relative demand for skill in this paper but our results also have important implications for the historical evolution of social mobility in the United States. Throughout much of the nineteenth century the pathway to middle class status was through ascending the agricultural ladder to farm operator status or via an apprenticeship to artisan status. By the end of the century, however, both pathways had narrowed, replaced by white collar occupations that, unlike farming or artisanal skills, required more formal schooling. Indeed, our new wage series imply that the demand for white collar skills increased relative to supply which suggests that the returns to schooling trended upwards during the much of the nineteenth century. Careful study of how the shifts in relative demand 
and wages influenced the decisions of individuals in the mid to late nineteenth century to invest in schooling rather than agricultural or artisan skills could shed considerable light on the historical evolution of the race between technology and education in the American case. 


\section{References}

Acemoglu, Daron and David H. Autor. 2010. “Skills, Tasks, and Technologies: Implications for

Employment and Earnings." O. Ashenfelter and D. Card, eds. $\underline{\text { Handbook of Labor }}$

Economics, Volume 4, Part B. New York: Elsevier.

Acemoglu, Daron and David H. Autor. 2012. "What Does Human Capital Do? A Review of Goldin and Katz's The Race between Education and Technology." Journal of Economic Literature 50: $426-463$.

Atack, Jeremy, and Fred Bateman. 1999. “U.S. Historical Statistics: Nineteenth Century U.S. Industrial Development through the Eyes of the Census of Manufactures," Historical Methods 32: 177-188.

Atack, Jeremy. 1979. "Fact or Fiction? The Relative Costs of Steam and Water Power:

A Simulation Approach." Explorations in Economic History 16: 409-437.

Atack, Jeremy; Fred Bateman; and Robert A. Margo. 2004. "Skill Intensity and Rising Wage Dispersion in Nineteenth Century American Manufacturing" Journal of Economic History 64: $172-192$.

Atack, Jeremy; Fred Bateman; and Robert A. Margo. 2005. "Capital Deepening and the Rise of the Factory: The American Experience in the Nineteenth Century," Economic History Review 58: 586-595.

Atack, Jeremy; Fred Bateman; and Robert A. Margo. 2008. "Steam Power, Establishment Size, 
and Labor Productivity Growth in Nineteenth Century American Manufacturing," Explorations in Economic History 45: 185-198.

Atack, Jeremy; Michael Haines; and Robert A. Margo. 2011. "Railroads and the Rise of the Factory: Evidence for the United States, 1850-1870," in J. Rosenbloom, D. Weiman, eds. Economic Evolution and Revolution in Historical Time, pp. 162-179. Palo Alto, CA: Stanford University Press.

Atack, Jeremy; Fred Bateman; and Thomas Weiss. 1980. "The Regional Diffusion and Adoption of the Steam Engine in American Manufacturing," Journal of Economic History 40: 281-308.

Autor, David H. 2010. "The Polarization of Job Opportunities in the U.S. Labor Market," Center for American Progress and The Hamilton Project, April.

Autor, David H. and David Dorn. 2012. "The Growth of Low-Skill Service Jobs and the Polarization of the U.S. Labor Market." American Economic Review, forthcoming.

Autor, David H. 2013. The "Task Approach" to Labor Markets: An Overview. Working Paper No. 18711, National Bureau of Economic Research, Cambridge MA.

Autor, David H.; Lawrence F. Katz; and Melissa S. Kearney. 2006. "The Polarization of the U.S. Labor Market," American Economic Review 96: 189-94.

Autor, David H.; Lawrence F. Katz; and Melissa S. Kearney. 2008. "Trends in U.S. Wage Inequality: Revising the Revisionists," Review of Economics and Statistics 90: 30023.

Autor, David H.; Lawrence F. Katz; and Alan B. Krueger. 1998. “Computing Inequality: Have Computers Changed the Labor Market?" Quarterly Journal of Economics 113: 1169- 
1213.

Autor, David H.; Frank Levy; and Richard J. Murnane. 2003. "The Skill Content of Recent Technological Change: An Empirical Exploration," Quarterly Journal of Economics 116: 1279-1333.

Bessen, Jim. 2012. “More Machines, Better Machines ... or Better Workers?” Journal of Economic History 72: 44-74.

Brissenden, Paul F. 1929. Earnings of Factory Workers, 1899-1927: An Analysis of Payroll Statistics. Washington DC: Government Printing Office.

Brown, Martin and Peter Phillips. 1986. "Craft Labor and Mechanization in Nineteenth Century Canning." Journal of Economic History 46: 743-756.

Chandler, Alfred. 1977. The Visible Hand: The Managerial Revolution in American Business. Cambridge MA: Harvard University Press.

Davis, Steven J. and John Haltiwanger. 1991. "Wage Dispersion Between and Within U.S. Manufacturing Plants, 1963-1986." In Brookings Papers on Economic Activity: Microeconomics 1991, pp. 115-180. Washington, DC: The Brookings Institution.

Delle Donne, C.R. 1973. Federal Census Schedules, 1850-1880: Primary Sources for Historical Research. National Archives and Records Service Reference Information Paper No. 67, General Services Administration, Washington DC.

Devine, Warren D. 1983. "From Shafts to Wires: Historical Perspective on Electrification," Journal of Economic History 43: 347-372. 
Engerman, Stanley and Kenneth Sokoloff. 2000. "Technology and Industrialization, 1790-1914."

In S. L. Engerman and R. Gallman, eds. The Cambridge Economic History of the

United States, Volume Two: The Long Nineteenth Century. New York: Cambridge

University Press.

Field, Alexander. 1980. “Industrialization and Skill Intensity: The Case of Massachusetts," Journal of Human Resources 15: 149-175.

Fenichel, A. H. 1966. "The Growth and Diffusion of Power in Manufacturing, 1839-1919," in Conference on Research on Income and Wealth, Output, Employment and Productivity in the United States After 1800. New York: National Bureau of Economic Research.

Goldin, Claudia. 1976. Urban Slavery in the American South, 1820-1860: A Quantitative

History. Chicago: University of Chicago Press.

Goldin, Claudia and Lawrence F. Katz. 1998. "The Origins of Technology-Skill Complementarity," Quarterly Journal of Economics 113: 693-732.

Goldin, Claudia and Lawrence F. Katz. 2000. "Education and Income in the Early Twentieth Century: Evidence from the Prairies," Journal of Economic History 60: 782-818.

Goldin, Claudia and Lawrence F. Katz. 2007. “Long-Run Changes in the Wage Structure: Narrowing, Widening, Polarizing." Brookings Papers on Economic Activity, no. 2: 135-67. 
Goldin, Claudia and Lawrence F. Katz. 2008. The Race between Education and Technology. Cambridge, MA: The Belknap Press of Harvard University Press.

Goldin, Claudia and Robert A. Margo. 1992. "The Great Compression: The Wage Structure in the United States at Mid-Century," Quarterly Journal of Economics 107: 1-34.

Goldin, Claudia, and Kenneth Sokoloff. 1982. "Women, Children, and Industrialization in the Early Republic: Evidence from the Manufacturing Censuses," Journal of Economic History 42: 741-774.

Goldin, Claudia and Kenneth Sokoloff. 1984. "The Relative Productivity Hypothesis of Industrialization," Quarterly Journal of Economics 99: 461-488.

Goos, Maarten; Alan Manning; and Anna Salomons. 2011. "Explaining Job Polarization: The Roles of Technology, Globalization, and Institutions," University of Leuven, November.

Griliches, Zvi. 1969. "Capital-Skill Complementarity." Review of Economics and Statistics 51: $465-68$.

Haines, Michael and Robert A. Margo. 2008. "Railroads and Local Economic Development: The United States in the 1850s." In J. Rosenbloom, ed. Quantitative Economic History: The Good of Counting. London: Routledge.

Hilt, Eric. 2008. "When Did Ownership Separate from Control? Corporate Governance in the Early Nineteenth Century." Journal of Economic History 68: 645-685.

Hounshell, David. 1984. From the American System to Mass Production. Baltimore, MD: John Hopkins Press. 
Hunter, Louis C. 1979. A History of Industrial Power in the United States: 1780 to 1930. Volume

One: Waterpower in the Century of the Steam Engine. Greenville, DE: Eleutherian MillsHagley Foundation.

Hunter, Louis C. 1985. A History of Industrial Power in the United States: 1780 to 1930. Volume Two: Steam Power. Greenville, DE: Eleutherian Mills-Hagley Foundation.

Hutchinson, William and Robert A. Margo. 2006. "The Impact of the Civil War on Capital Intensity and Labor Productivity in Southern Manufacturing," Explorations in Economic History 43: 689-704.

IPUMS-USA. Undated. “Integrated Occupation and Industry Codes and Occupation Standing Variables in the IPUMS." http://usa.ipums.org/usa/chapter4/chapter4.shtml Lamoreaux, Naomi. 2006. “Business Organization” In S. Carter, et.al., eds. $\underline{\text { Historical }}$ Statistics of the United States: Earliest Times to the Present, Millennial Edition, Volume 3, Part C: Economic Structure and Performance. New York: Cambridge University Press.

Margo, Robert A. 2000. Wages and Labor Markets in the United States, 1820-1860. Chicago: University of Chicago Press.

Margo, Robert A. 2002. "The North-South Wage Gap, Before and After the Civil War." National Bureau of Economic Research Working Paper No. 8778, February.

Margo, Robert A. 2004. "The North-South Wage Gap, Before and After the Civil War." In D. Eltis, F. Lewis, and K. Sokoloff, eds. Slavery in the Development of the Americas. New York: Cambridge University Press.

Olson, John F. 1992. "The Occupational Structure of Southern Plantations during the Late 
Antebellum Era." In R. W. Fogel and S. L. Engerman, eds. Without Consent or

Contract, Markets and Production, Technical Papers, Volume 1. New York: W.W. Norton.

Rosenbloom, Joshua. 2002. Looking for Work: Searching for Workers: Labor Markets

During American Industrialization. New York: Cambridge University Press.

Rosenthal, Caitlin C. 2012. From Memory to Mastery: Accounting for Control in America,

1750-1880. PhD dissertation, Department of History, Harvard University.

Rousseau, Peter and Richard Sylla. 2005. “Emerging Financial Markets and Early U.S.

Growth." Explorations in Economic History 42: 1-26.

Scranton, Phillip. 1999. Endless Novelty: Specialty Production and American Industrialization, 1865-1925. Princeton: Princeton University Press.

Sokoloff, Kenneth. 1982. Industrialization and the Growth of the Manufacturing Sector in the Northeast, 1820-1850. Unpublished PhD dissertation, Department of Economics, Harvard University.

Sokoloff, Kenneth. 1984. "Was the Transition from the Artisanal Shop to the Non-Mechanized Factory Associated with Gains in Efficiency? Evidence From the Manufacturing Censuses of 1820 and 1850," Explorations in Economic History 21: 351-384.

Sokoloff, Kenneth. 1986. "Productivity Gains in Manufacturing During Early Industrialization: Evidence from the American Northeast, 1820-1850." In S. L. Engerman and R. Gallman, Eds. Long Term Factors in American Economic Growth, 51: Studies in Income and Wealth. Chicago: University of Chicago Press. 
Taylor, George R. 1951. The Transportation Revolution, 1815-1860. New York: Holt-Rinehart and Winston.

Temin, Peter. 1966. "Steam and Waterpower in the Early Nineteenth Century." Journal of Economic History 26: 187-205.

Uselding, Paul. 1972. "Technical Progress at the Springfield Armory, 1820-1850." Explorations in Economic History 9: 291-316.

U.S. Bureau of Labor. 1899. Thirteenth Annual Report of the Commissioner of Labor, 1898. Two Volumes, Washington DC: Government Printing Office.

Weiss, Thomas. 2006. “Workforce." In Susan B. Carter, Scott Sigmund Gartner, Michael R. Haines, Alan L. Olmstead, Richard Sutch, and Gavin Wright, eds. $\underline{\text { Historical Statistics }}$ Of the United States, Earliest Times to the Present, Millennial Edition, Volume Two, Part B, Work and Welfare. New York: Cambridge University Press.

Williamson, Jeffrey and Peter Lindert. 1980. American Inequality: A Macroeconomic History. New York: Academic Press.

Wright, Carroll D. 1900. The History and Growth of the United States Census. Washington, DC: U.S. Government Printing Office.

Wright, Gavin. 1990. "The Origins of American Industrial Success, 1879-1940," American 
Economic Review 80: 651-668. 
Table 1: Nominal Capital-Labor Ratios in Manufacturing, 1850 and 1880

\begin{tabular}{|c|c|c|c|c|c|c|c|c|}
\hline & $\begin{array}{l}1-5 \\
\text { Workers }\end{array}$ & $6-15$ & $16-100$ & $100+$ & $\begin{array}{l}1-5 \\
\text { Workers }\end{array}$ & $6-15$ & $16-100$ & $100+$ \\
\hline $\begin{array}{l}\text { Adjustment for } \\
\text { Entrepreneurial } \\
\text { Labor Input? }\end{array}$ & No & No & No & No & Yes & Yes & Yes & Yes \\
\hline $\begin{array}{l}\text { Adjustment for } \\
\text { Working } \\
\text { Capital }\end{array}$ & No & No & No & No & Yes & Yes & Yes & Yes \\
\hline $\begin{array}{l}1850 \text { Sample } \\
\text { Mean, Ln (K/L) }\end{array}$ & 5.77 & 5.70 & 5.75 & 5.74 & 5.88 & 6.08 & 6.18 & 6.08 \\
\hline $\begin{array}{l}1880 \text { Sample } \\
\text { Mean }\end{array}$ & 6.17 & 6.05 & 6.26 & 6.03 & 6.20 & 6.41 & 6.65 & 6.47 \\
\hline$\Delta(1880-1850)$ & 0.40 & 0.35 & 0.51 & 0.28 & 0.32 & 0.33 & 0.47 & 0.39 \\
\hline $\begin{array}{l}\Delta(1880-1850), \\
\text { relative to } 1-5 \\
\text { workers }\end{array}$ & & $\begin{array}{c}-0.05 \\
(0.08)\end{array}$ & $\begin{array}{c}0.11 \\
(0.07)\end{array}$ & $\begin{array}{l}-0.12 \\
(0.07)\end{array}$ & & $\begin{array}{c}0.01 \\
(0.06)\end{array}$ & $\begin{array}{c}0.15^{*} \\
(0.05)\end{array}$ & $\begin{array}{c}0.07 \\
(0.05)\end{array}$ \\
\hline $\begin{array}{l}\text { Regression } \\
\text { Adjusted, } \Delta \\
\text { (1880-1850), } \\
\text { relative to 1-5 } \\
\text { workers }\end{array}$ & & $\begin{array}{l}-0.09 \\
(0.06)\end{array}$ & $\begin{array}{c}0.21 * \\
(0.05)\end{array}$ & $\begin{array}{c}0.28 * \\
(0.07)\end{array}$ & & $\begin{array}{l}-0.10 \\
(0.04)\end{array}$ & $\begin{array}{c}0.16^{*} \\
(0.04)\end{array}$ & $\begin{array}{c}0.37^{*} \\
(0.05)\end{array}$ \\
\hline $\begin{array}{l}\text { 1850, Share of } \\
\text { Employment } \\
\text { in: }\end{array}$ & 0.214 & 0.164 & 0.343 & 0.279 & 0.241 & 0.177 & 0.309 & 0.273 \\
\hline $\begin{array}{l}\text { 1880, Share of } \\
\text { Employment } \\
\text { in: }\end{array}$ & 0.141 & 0.139 & 0.335 & 0.385 & 0.158 & 0.152 & 0.321 & 0.369 \\
\hline $\begin{array}{l}\Delta \text { (Share of } \\
\text { Employment) }\end{array}$ & -0.073 & -0.025 & -0.008 & 0.106 & -0.083 & -0.025 & 0.012 & 0.096 \\
\hline
\end{tabular}

Source: 1850 and 1880 Atack-Bateman national manufacturing samples; see Atack and Bateman (1999).

Adjustment for entrepreneurial labor input and working capital: see text and Atack, Bateman, and Margo (2005, p. 587, footnote 7). Establishments are included in the sample if they reported positive employment (males + females $>0$ in 1850 and children + adult females + adult males $>0$ in 1880), capital invested, outputs produced, raw materials, and value added (value of output - value of raw materials). We also deleted observations whose estimated rate of return on capital invested in either census year fell outside the 1st through $99^{\text {th }}$ percentiles of the distribution of such returns (see Atack, Bateman, and Margo (2005)) as well as observations in miscellaneous manufacturing (SIC $=999)$ and gas works and distribution (SIC = 492). These assumptions assure compatibility with the samples analyzed in Atack, Bateman, and Margo (2005). We also exclude establishments reporting more than 1,000 workers (only a handful of establishments fall into this group). Regression adjusted changes from 1850 to 1880: the reported coefficient in each column is the coefficient on the interaction between size class of establishment (e.g. 6-15 workers, 16-100, 100+) and dummy variable for year $=1880$; the regression also 
includes a dummy variable for year $=1880$, integer values of the total number of workers hired, dummy variables for urban status (establishment located in a city or town of population 2,500 or larger), state, and 3-digit SIC industry code; 1850 and 1880 samples are pooled to estimate the regressions. Standard errors are shown in parentheses; ${ }^{*}=$ significant at the 5 percent level. There are 4,905 establishments in the 1850 sample and 7,175 establishments in the 1880 sample. 
Table 2: Regressions of Percent Female (1850-60) or Percent Female and Child (1870-80): U.S. Manufacturing Establishments, 1850-1880

Panel A: $1850-1860$

\begin{tabular}{|c|c|c|c|c|c|c|c|}
\hline Sample & Pooled & Pooled & 1850 & 1860 & $\begin{array}{l}\text { Pooled, } \\
\text { Steam } \\
\text { Powered }\end{array}$ & $\begin{array}{l}\text { Pooled, } \\
\text { Water } \\
\text { Powered }\end{array}$ & $\begin{array}{l}\text { Pooled, } \\
\text { Non- } \\
\text { Powered }\end{array}$ \\
\hline $\begin{array}{l}\text { Dependent } \\
\text { Variable }\end{array}$ & $\begin{array}{l}\text { Percent } \\
\text { Female }\end{array}$ & $\begin{array}{l}\text { Percent } \\
\text { Female }\end{array}$ & $\begin{array}{l}\text { Percent } \\
\text { Female, } \\
\text { County } \\
\text { Fixed } \\
\text { Effects }\end{array}$ & $\begin{array}{l}\text { Percent } \\
\text { Female, } \\
\text { County } \\
\text { Fixed } \\
\text { Effects }\end{array}$ & $\begin{array}{l}\text { Percent } \\
\text { Female }\end{array}$ & $\begin{array}{l}\text { Percent } \\
\text { Female }\end{array}$ & $\begin{array}{l}\text { Percent } \\
\text { Female }\end{array}$ \\
\hline $\begin{array}{l}\text { Steam Power }= \\
1\end{array}$ & $\begin{array}{c}0.012^{*} \\
(0.005) \\
\left\{0.014^{*}\right\}\end{array}$ & $\begin{array}{l}-0.030^{*} \\
(0.005) \\
\left\{-0.028^{*}\right\}\end{array}$ & $\begin{array}{l}-0.041^{*} \\
(0.009)\end{array}$ & $\begin{array}{l}-0.018^{*} \\
(0.007)\end{array}$ & & & \\
\hline $\begin{array}{l}\text { Water Power }= \\
1\end{array}$ & $\begin{array}{c}0.003 \\
(0.005) \\
\{0.007\}\end{array}$ & $\begin{array}{l}-0.005 \\
(0.004) \\
\{-0.005\} \\
\end{array}$ & $\begin{array}{l}-0.003 \\
(0.008)\end{array}$ & $\begin{array}{l}-0.005 \\
(0.007)\end{array}$ & & & \\
\hline $\begin{array}{l}\text { Ln } \\
\text { (Capital/Value } \\
\text { Added) } \times 10^{-1}\end{array}$ & $\begin{array}{c}0.014 \\
(0.010) \\
\{0.010\}\end{array}$ & $\begin{array}{c}0.018 \\
(0.013) \\
\{0.011\}\end{array}$ & $\begin{array}{c}0.040 \\
(0.022)\end{array}$ & $\begin{array}{l}-0.017 \\
(0.020)\end{array}$ & $\begin{array}{l}-0.011 \\
(0.033) \\
\{-0.009\}\end{array}$ & $\begin{array}{c}0.027 \\
(0.018) \\
\{0.028\}\end{array}$ & $\begin{array}{c}0.021 \\
(0.019) \\
\{0.019\}\end{array}$ \\
\hline $\begin{array}{l}\text { Ln (\# of } \\
\text { workers) }\end{array}$ & & $\begin{array}{l}0.043^{*} \\
(0.001) \\
\left\{0.042^{*}\right\}\end{array}$ & $\begin{array}{c}0.051^{*} \\
(0.002)\end{array}$ & $\begin{array}{c}0.034^{*} \\
(0.002)\end{array}$ & $\begin{array}{l}0.023^{*} \\
(0.003) \\
\left\{0.022^{*}\right\}\end{array}$ & $\begin{array}{l}0.040^{*} \\
(0.002) \\
\left\{0.041^{*}\right\}\end{array}$ & $\begin{array}{c}0.049^{*} \\
(0.002) \\
\left\{0.047^{*}\right\}\end{array}$ \\
\hline $\begin{array}{l}\text { Mean value of } \\
\text { dependent } \\
\text { variable }\end{array}$ & $\begin{array}{c}0.052 \\
{[0.231]}\end{array}$ & $\begin{array}{l}0.052 \\
{[0.231]}\end{array}$ & $\begin{array}{c}0.055 \\
{[0.219]}\end{array}$ & $\begin{array}{c}0.048 \\
{[0.243]}\end{array}$ & $\begin{array}{c}0.034 \\
{[0.102]}\end{array}$ & $\begin{array}{c}0.036 \\
{[0.390]}\end{array}$ & $\begin{array}{c}0.062 \\
{[0.206]}\end{array}$ \\
\hline $\begin{array}{l}\text { Mean value, \# } \\
\text { of workers }\end{array}$ & 9.41 & 9.41 & 9.04 & 9.78 & 18.59 & 9.13 & 7.87 \\
\hline $\begin{array}{l}\text { Adjusted R- } \\
\text { Square }\end{array}$ & 0.492 & 0.546 & 0.513 & 0.510 & 0.539 & 0.660 & 0.529 \\
\hline $\begin{array}{l}\text { \# of } \\
\text { establishments }\end{array}$ & 10,122 & 10,122 & 5,039 & & 1,144 & 2,646 & 6,332 \\
\hline
\end{tabular}

Source: 1850 and 1860 samples of manufacturing establishments, Atack and Bateman (1999). Pooled Regressions include dummies for urban status, 3-digit (SIC) industry code, year (1860), state, and state $x$ year. Coefficients in \{\} are for regressions with county fixed effects rather than state fixed effects. Nonpowered establishments include observations for which the power source is not reported. Numbers in [] are mean of the dependent variable when establishments are weighted by reported employment. *: significant at 5 percent level. 
Panel B: $1870-1880$

\begin{tabular}{|c|c|c|c|c|c|c|c|}
\hline Sample & Pooled & Pooled & 1870 & 1880 & $\begin{array}{l}\text { Pooled, } \\
\text { Steam } \\
\text { Powered }\end{array}$ & $\begin{array}{l}\text { Pooled, } \\
\text { Water } \\
\text { Powered }\end{array}$ & $\begin{array}{l}\text { Pooled, } \\
\text { Non- } \\
\text { Powered }\end{array}$ \\
\hline $\begin{array}{l}\text { Dependent } \\
\text { Variable }\end{array}$ & $\begin{array}{l}\text { Percent } \\
\text { Female } \\
\text { and Child }\end{array}$ & $\begin{array}{l}\text { Percent } \\
\text { Female } \\
\text { and Child }\end{array}$ & $\begin{array}{l}\text { Percent } \\
\text { Female } \\
\text { and Child, } \\
\text { County } \\
\text { Fixed } \\
\text { Effects }\end{array}$ & $\begin{array}{l}\text { Percent } \\
\text { Female } \\
\text { and Child, } \\
\text { County } \\
\text { Fixed } \\
\text { Effects }\end{array}$ & $\begin{array}{l}\text { Percent } \\
\text { Female } \\
\text { and Child }\end{array}$ & $\begin{array}{l}\text { Percent } \\
\text { Female } \\
\text { and Child }\end{array}$ & $\begin{array}{l}\text { Percent } \\
\text { Female } \\
\text { and Child }\end{array}$ \\
\hline $\begin{array}{l}\text { Steam Power = } \\
1\end{array}$ & $\begin{array}{c}0.021^{*} \\
(0.005) \\
\left\{0.024^{*}\right\}\end{array}$ & $\begin{array}{l}-0.029^{*} \\
(0.005) \\
\left\{-0.026^{*}\right\}\end{array}$ & $\begin{array}{l}-0.023^{*} \\
(0.010)\end{array}$ & $\begin{array}{l}-0.029 * \\
(0.008)\end{array}$ & & & \\
\hline $\begin{array}{l}\text { Water Power }= \\
1\end{array}$ & $\begin{array}{l}-0.008 \\
(0.007) \\
\{-0.010\}\end{array}$ & $\begin{array}{l}-0.025^{*} \\
(0.0070 \\
\left\{-0.027^{*}\right\}\end{array}$ & $\begin{array}{l}-0.017 \\
(0.013)\end{array}$ & $\begin{array}{l}-0.034^{*} \\
(0.010)\end{array}$ & & & \\
\hline $\begin{array}{l}\text { Ln } \\
\text { (Capital/Value } \\
\text { Added) } \times 10^{-1}\end{array}$ & $\begin{array}{l}-0.017 \\
(0.016) \\
\{-0.028\}\end{array}$ & $\begin{array}{l}-0.029 \\
(0.016) \\
\left\{-0.043^{*}\right\}\end{array}$ & $\begin{array}{l}-0.044 \\
(0.030)\end{array}$ & $\begin{array}{l}-0.041^{*} \\
(0.023)\end{array}$ & $\begin{array}{l}-0.006 \\
(0.030) \\
\{-0.031\}\end{array}$ & $\begin{array}{c}0.015 \\
(0.024) \\
\{0.026\}\end{array}$ & $\begin{array}{l}-0.048^{*} \\
(0.022) \\
\{-0.052 *\}\end{array}$ \\
\hline $\begin{array}{l}\text { Ln (\# of } \\
\text { workers) }\end{array}$ & & $\begin{array}{c}0.041^{*} \\
(0.017)\end{array}$ & $\begin{array}{c}0.045^{*} \\
(0.003)\end{array}$ & $\begin{array}{c}0.038^{*} \\
(0.002)\end{array}$ & $\begin{array}{l}0.028^{*} \\
(0.003) \\
\{0.028 *\}\end{array}$ & $\begin{array}{c}0.026 * \\
(0.030) \\
\left\{0.023^{*}\right\}\end{array}$ & $\begin{array}{c}0.046^{*} \\
(0.002) \\
\left\{0.046^{*}\right\}\end{array}$ \\
\hline $\begin{array}{l}\text { Mean of } \\
\text { Dependent } \\
\text { Variable }\end{array}$ & $\begin{array}{c}0.077 \\
{[0.270]}\end{array}$ & $\begin{array}{l}0.077 \\
{[0.270]}\end{array}$ & $\begin{array}{c}0.077 \\
{[0.239]}\end{array}$ & $\begin{array}{c}0.077 \\
{[0.286]}\end{array}$ & $\begin{array}{c}0.081 \\
{[0.236]}\end{array}$ & $\begin{array}{c}0.033 \\
(0.200)\end{array}$ & $\begin{array}{c}0.085 \\
{[0.330]}\end{array}$ \\
\hline $\begin{array}{l}\text { Mean of \# of } \\
\text { workers }\end{array}$ & 12.36 & 12.36 & 12.89 & 12.08 & 27.51 & 10.07 & 7.47 \\
\hline $\begin{array}{l}\text { Adjusted R- } \\
\text { Square }\end{array}$ & 0.347 & 0.383 & 0.360 & 0.323 & 0.361 & 0.548 & 0.375 \\
\hline $\begin{array}{l}\text { Number of } \\
\text { Establishments }\end{array}$ & 11,084 & 11,084 & 3,885 & 7,199 & 2,323 & 1,464 & 7,208 \\
\hline
\end{tabular}

Source: 1870 and 1880 samples of manufacturing establishments, Atack and Bateman (1999).

Regressions include dummies for urban status, 3-digit (SIC) industry code, year (1880), state, and state $x$ year. Coefficients in \{\} are for regressions with county fixed effects rather than state fixed effects. 1880 observations are re-weighted to correct for under-reporting of special agent establishments; see Atack, Bateman, and Margo (2004). Non-powered establishments include observations with un-reported power source. Numbers in [] are the mean of the dependent variable when establishments are weighted by reported employment. 
Table 3: Regressions of Reporting of Skilled Daily Wages and of Estimated Percent Unskilled: Manufacturing Establishments in 1880

Panel A: Report of Skilled Daily Wage: 1880 Manufacturing Establishments

\begin{tabular}{|l|l|l|l|l|}
\hline & $\begin{array}{l}\text { Artisan Wage } \\
\text { Reported Only }\end{array}$ & $\begin{array}{l}\text { Artisan Wage } \\
\text { Reported Only }\end{array}$ & $\begin{array}{l}\text { Both Artisan and } \\
\text { Unskilled Wage } \\
\text { Reported }\end{array}$ & $\begin{array}{l}\text { Both Artisan and } \\
\text { Unskilled Wage } \\
\text { Reported }\end{array}$ \\
\hline Ln (\# of workers) & $\begin{array}{l}-0.075^{*} \\
(0.010)\end{array}$ & $\begin{array}{l}-0.052^{*} \\
(0.010)\end{array}$ & $\begin{array}{l}0.089^{*} \\
(0.011)\end{array}$ & $\begin{array}{c}0.061^{*} \\
(0.011)\end{array}$ \\
\hline $\begin{array}{l}\text { Ln } \\
\text { (Capital/Workers) }\end{array}$ & & $\begin{array}{l}0.013^{*} \\
(0.005)\end{array}$ & & -0.002 \\
\hline Steam Power =1 & & $-0.165^{*}$ & & $0.006)$ \\
\hline Water Power =1 & & $(0.016)$ & & $0.201^{*}$ \\
& & $-0.083^{*}$ & & $0.017)$ \\
\hline Sample Mean of & 0.245 & $(0.021)$ & $0.045^{*}$ \\
Dependent & & 0.245 & 0.667 & $0.023)$ \\
Variable & & & & 0.667 \\
\hline Adjusted R-square & 0.113 & 0.126 & 0.095 & 0.113 \\
\hline
\end{tabular}

Source: 1880 Atack-Bateman manufacturing sample. Number of establishments is 7,119.

Establishments are re-weighted to correct for under-sampling of special agent establishments; see text and Atack, Bateman, and Margo (2004). 
Panel B: Percent Unskilled

\begin{tabular}{|c|c|c|c|c|c|c|}
\hline $\begin{array}{l}\text { Dependent } \\
\text { Variable }\end{array}$ & $\begin{array}{l}\text { Percent } \\
\text { Unskilled }\end{array}$ & $\begin{array}{l}\text { Percent } \\
\text { Unskilled }\end{array}$ & $\begin{array}{l}\text { Percent } \\
\text { Unskilled }\end{array}$ & $\begin{array}{l}\text { Percent } \\
\text { Unskilled, } \\
\text { Steam } \\
\text { Powered } \\
\text { Establishments }\end{array}$ & $\begin{array}{l}\text { Percent } \\
\text { Unskilled, } \\
\text { Water } \\
\text { Powered } \\
\text { Establishments }\end{array}$ & $\begin{array}{l}\text { Percent } \\
\text { Unskilled, } \\
\text { Non-Powered } \\
\text { Establishments }\end{array}$ \\
\hline $\begin{array}{l}\text { Steam Power }= \\
1\end{array}$ & $\begin{array}{c}0.130^{*} \\
(0.019) \\
\left\{0.145^{*}\right\}\end{array}$ & $\begin{array}{c}0.005 \\
(0.021) \\
\{0.016\}\end{array}$ & $\begin{array}{c}0.005 \\
(0.021) \\
\{0.016\}\end{array}$ & & & \\
\hline $\begin{array}{l}\text { Water Power }= \\
1\end{array}$ & $\begin{array}{c}0.076^{*} \\
(0.027) \\
\left\{0.070^{*}\right\}\end{array}$ & $\begin{array}{c}0.032 \\
(0.027) \\
\{0.030\}\end{array}$ & $\begin{array}{c}0.033 \\
(0.027) \\
\{0.030) \\
\end{array}$ & & & \\
\hline $\begin{array}{l}\text { Ln } \\
\text { (Capital/Value } \\
\text { Added) }\end{array}$ & $\begin{array}{c}0.015^{*} \\
(0.006) \\
\left\{0.016^{*}\right\}\end{array}$ & $\begin{array}{l}0.014^{*} \\
(0.006) \\
\left(0.013^{*}\right\}\end{array}$ & $\begin{array}{c}0.014 * \\
(0.006) \\
\{0.013\}\end{array}$ & $\begin{array}{c}0.006 \\
(0.014) \\
\{0.012\}\end{array}$ & $\begin{array}{c}0.006 \\
(0.019) \\
\{0.043\}\end{array}$ & $\begin{array}{c}0.017^{*} \\
(0.007) \\
\{0.015\}\end{array}$ \\
\hline $\begin{array}{l}\text { Ln (\# of } \\
\text { workers) }\end{array}$ & & $\begin{array}{l}0.090^{*} \\
(0.006) \\
\left\{0.091^{*}\right\}\end{array}$ & $\begin{array}{c}0.090 * \\
(0.006) \\
\{0.091\}\end{array}$ & $\begin{array}{c}0.077^{*} \\
(0.012) \\
\left\{0.085^{*}\right\}\end{array}$ & $\begin{array}{c}0.035 \\
(0.029) \\
\{-0.01\}\end{array}$ & $\begin{array}{c}0.096 * \\
(0.008) \\
\left\{0.096^{*}\right\}\end{array}$ \\
\hline $\begin{array}{l}\text { Controls for } \\
\text { Operating } \\
\text { Times? }\end{array}$ & No & No & Yes & Yes & Yes & Yes \\
\hline $\begin{array}{l}\text { Adjusted R- } \\
\text { Square }\end{array}$ & 0.147 & 0.188 & 0.188 & 0.168 & $\begin{array}{c}0.038 \\
\{-0.026\}\end{array}$ & 0.123 \\
\hline $\begin{array}{l}\text { Sample Mean, } \\
\text { Dependent } \\
\text { Variable }\end{array}$ & $\begin{array}{c}0.428 \\
{[0.685]}\end{array}$ & $\begin{array}{l}0.428 \\
{[0.685]}\end{array}$ & $\begin{array}{l}0.428 \\
{[0.685]}\end{array}$ & $\begin{array}{c}0.609 \\
{[0.745]}\end{array}$ & $\begin{array}{c}0.606 \\
{[0.640]}\end{array}$ & $\begin{array}{c}0.349 \\
\{0.391\}\end{array}$ \\
\hline $\begin{array}{l}\text { Mean Value, \# } \\
\text { of Workers }\end{array}$ & 11.30 & 11.30 & 11.30 & 30.3 & 3.90 & 6.41 \\
\hline $\begin{array}{l}\text { Number of } \\
\text { Establishments }\end{array}$ & 4,428 & 4,428 & 4,428 & 796 & 506 & 3,084 \\
\hline
\end{tabular}

Source: 1880 Atack-Bateman sample of manufacturing establishments (Atack and Bateman 1999). See Appendix A for construction of dependent variable. Establishments are re-weighted to correct for under-reporting of special agent industries; see Atack, Bateman, and Margo (2004). All regressions include dummy variables for urban status, 3-digit industry (SIC) code, and state; coefficients in \{\} are from regressions with county fixed effects instead of state fixed effects. Mean values shown in brackets re-weight establishments by reported employment (adjusted for under-reporting of special agent industries). 
Table 4: Occupation Distributions: U.S. Labor Force, Age 10 and over: 1850-1910

Panel A: Manufacturing Industries

\begin{tabular}{|l|l|l|l|l|l|l|}
\hline & 1850 & 1860 & 1870 & 1880 & 1900 & 1910 \\
\hline White Collar & $\mathbf{3 . 1 \%}$ & $\mathbf{3 . 2 \%}$ & $\mathbf{4 . 8 \%}$ & $\mathbf{4 . 7 \%}$ & $\mathbf{6 . 8 \%}$ & $\mathbf{1 1 . 9 \%}$ \\
\hline Prof-Tech-Manager & 3.0 & 3.1 & 4.2 & 4.0 & 5.2 & 5.6 \\
\hline Clerical-Sales & 0.1 & 0.1 & 0.6 & 0.7 & 1.6 & 6.3 \\
\hline Skilled Blue Collar & $\mathbf{3 9 . 4}$ & $\mathbf{3 8 . 5}$ & $\mathbf{3 1 . 8}$ & $\mathbf{2 9 . 2}$ & $\mathbf{2 8 . 7}$ & $\mathbf{2 2 . 8}$ \\
\hline $\begin{array}{l}\text { Middle Skill 2 } \\
\text { (Skilled Blue Collar } \\
\text { +Clerical/Sales) }\end{array}$ & $\mathbf{3 9 . 5}$ & $\mathbf{3 8 . 6}$ & $\mathbf{3 2 . 4}$ & $\mathbf{2 9 . 9}$ & $\mathbf{3 0 . 3}$ & $\mathbf{2 9 . 1}$ \\
\hline Operative/Unskilled & $\mathbf{5 7 . 5}$ & $\mathbf{5 8 . 3}$ & $\mathbf{6 3 . 4}$ & $\mathbf{6 7 . 8}$ & $\mathbf{6 4 . 5}$ & $\mathbf{6 5 . 4}$ \\
\hline
\end{tabular}

Source: 1850 to 1910 Census IPUMS; see Appendix B. Manager: includes Proprietors and Officials.

Panel B: Aggregate Economy

\begin{tabular}{|l|l|l|l|l|l|l|}
\hline & 1850 & 1860 & 1870 & 1880 & 1900 & 1910 \\
\hline White Collar & $\mathbf{6 . 9 \%}$ & $\mathbf{8 . 3 \%}$ & $\mathbf{1 0 . 6 \%}$ & $\mathbf{1 1 . 6 \%}$ & $\mathbf{1 7 . 1 \%}$ & $\mathbf{1 9 . 7 \%}$ \\
\hline Professional-Technical & 2.3 & 2.6 & 2.9 & 3.4 & 4.3 & 4.6 \\
\hline Manager & 3.1 & 3.6 & 4.4 & 4.3 & 5.7 & 5.6 \\
\hline Clerical/Sales & 1.5 & 2.1 & 3.3 & 3.9 & 7.2 & 9.5 \\
\hline Skilled Blue Collar & $\mathbf{1 1 . 6}$ & $\mathbf{1 1 . 2}$ & $\mathbf{1 0 . 7}$ & $\mathbf{9 . 1}$ & $\mathbf{1 1 . 0}$ & $\mathbf{1 1 . 9}$ \\
\hline Operative/Unskilled/Service & $\mathbf{2 8 . 7}$ & $\mathbf{3 0 . 1}$ & $\mathbf{3 2 . 4}$ & $\mathbf{3 7 . 7}$ & $\mathbf{3 6 . 4}$ & $\mathbf{3 7 . 9}$ \\
\hline Agriculture & $\mathbf{5 2 . 7}$ & $\mathbf{5 0 . 5}$ & $\mathbf{4 6 . 4}$ & $\mathbf{4 1 . 6}$ & $\mathbf{3 5 . 3}$ & $\mathbf{3 0 . 5}$ \\
\hline Operator/Supervisory & 23.9 & 23.2 & 24.8 & 24.8 & 20.0 & 16.6 \\
\hline Farm Laborer & 28.8 & 27.3 & 21.6 & 16.8 & 15.5 & 13.9 \\
\hline
\end{tabular}

Source: 1850 to 1910 Census IPUMS; see Appendix B.

Panel C: Skill Groups, Aggregate Economy

\begin{tabular}{|l|l|l|l|l|l|l|}
\hline & 1850 & 1860 & 1870 & 1880 & 1900 & 1910 \\
\hline High Skill 1 (White Collar) & $6.9 \%$ & $8.3 \%$ & $10.6 \%$ & $11.6 \%$ & $17.1 \%$ & $19.7 \%$ \\
\hline $\begin{array}{l}\text { High Skill 2 } \\
\text { (Prof/Tech/Man) }\end{array}$ & 5.4 & 6.2 & 7.3 & 7.7 & 10.0 & 10.2 \\
\hline $\begin{array}{l}\text { Middle Skill 1 (Blue Collar } \\
+ \text { Agricultural } \\
\text { Operator/Supervisory) }\end{array}$ & 35.6 & 34.3 & 35.5 & 33.9 & 31.1 & 28.5 \\
\hline $\begin{array}{l}\text { Middle Skill 2 (\#1 + } \\
\text { Clerical/Sales) }\end{array}$ & 37.1 & 36.2 & 38.8 & 37.8 & 38.3 & 38.0 \\
\hline $\begin{array}{l}\text { \% Low Skill (Oper/ } \\
\text { Unsk/Serv/Farm Lab) }\end{array}$ & 57.5 & 57.4 & 54.0 & 54.5 & 51.9 & 51.8 \\
\hline
\end{tabular}

Source: Computed from Panel B. 
Table 5: Wages of Common Labor, Skilled Artisans, and White Collar Workers: Aggregate Time Series, $1820-1880$ by Five-Year Periods and by Decades

Panel A: Nominal Wage Series

\begin{tabular}{|l|l|l|l|}
\hline & Common Labor & Skilled Artisan & White Collar \\
\hline Pay Period & Day & Day & Month \\
\hline $1821-25$ & $\$ 0.71$ & $\$ 1.31$ & $\$ 33.62$ \\
\hline $1826-30$ & 0.70 & 1.38 & 35.12 \\
\hline $1831-35$ & 0.73 & 1.45 & 35.23 \\
\hline $1836-40$ & 0.82 & 1.56 & 43.75 \\
\hline $1841-45$ & 0.79 & 1.40 & 42.43 \\
\hline $1846-50$ & 0.81 & 1.41 & 44.70 \\
\hline $1851-55$ & 0.90 & 1.57 & 51.00 \\
\hline $1856-60$ & 1.01 & 1.83 & 52.29 \\
\hline $1866-70$ & 1.47 & 2.47 & 71.52 \\
\hline $1871-75$ & 1.40 & 2.64 & 74.38 \\
\hline $1876-80$ & 1.11 & 2.29 & 72.69 \\
\hline $1821-30$ & 0.70 & 1.36 & 34.45 \\
\hline $1831-40$ & 0.78 & 1.51 & 39.49 \\
\hline $1841-50$ & 0.80 & 1.40 & 43.56 \\
\hline $1851-60$ & 0.95 & 1.70 & 51.65 \\
\hline $1861-70$ & 1.47 & 2.47 & 71.52 \\
\hline $1871-80$ & 1.26 & 2.46 & 73.53 \\
\hline Coefficient of Linear & 0.0135 & 0.0127 & 0.0159 \\
\hline Time Trend, Log Wage & $(0.0011)$ & $(0.0010)$ & $(0.0006)$ \\
Regression & & & \\
\hline
\end{tabular}

Source: see Appendix C. Standard error of coefficient reported in parentheses.

Panel B: Wage Ratios

\begin{tabular}{|l|l|l|l|}
\hline & Artisan/Common Labor & Clerk/Common Labor & Clerk/Artisan \\
\hline $1821-30$ & 1.94 & 1.89 & 0.97 \\
\hline $1831-40$ & 1.94 & 1.95 & 1.01 \\
\hline $1841-50$ & 1.75 & 2.09 & 1.19 \\
\hline $1851-60$ & 1.79 & 2.09 & 1.17 \\
\hline $1861-70$ & 1.68 & 1.87 & 1.11 \\
\hline $1871-80$ & 1.95 & 2.24 & 1.15 \\
\hline
\end{tabular}

Source: computed from Panel A. Wages ratios for clerks assume 26 days per month (daily wage $=$ monthly wage/26); see Margo (2000). 
Table 6: Occupation Distributions (in Percent): U.S. Civilian Employment, Age 16 and Over, 1920 to 2010

\section{Panel A: Aggregate Economy}

\begin{tabular}{|c|c|c|c|c|c|c|c|c|c|c|}
\hline Detailed Occupations & 1920 & 1930 & 1940 & 1950 & 1960 & 1970 & 1980 & 1990 & 2000 & 2010 \\
\hline White Collar & 25.5 & 30.8 & 31.9 & 37.5 & 43.3 & 48.5 & 53.8 & 58.8 & 61.8 & 62.5 \\
\hline Professional-Technical & 5.6 & 6.9 & 7.7 & 8.9 & 11.9 & 15.5 & 17.5 & 20.4 & 23.4 & 25.1 \\
\hline Manager & 6.7 & 7.8 & 8.0 & 9.0 & 8.9 & 7.9 & 10.4 & 12.8 & 14.2 & 14.3 \\
\hline Clerical/Sales & 13.1 & 16.1 & 16.2 & 19.6 & 22.6 & 25.1 & 25.9 & 25.5 & 24.2 & 23.1 \\
\hline Skilled Blue Collar (Craft) & 14.1 & 12.7 & 11.6 & 14 & 14.3 & 13.6 & 12 & 10.5 & 9.8 & 8.1 \\
\hline Operative/Laborer/Service & 35.5 & 34.2 & 39.1 & 36.8 & 36 & 34.8 & 31.9 & 29.2 & 27.1 & 28.3 \\
\hline Operative/Laborer & 27.3 & 24.3 & 27.4 & 26.5 & 24.4 & 22.1 & 19.2 & 15.9 & 14.1 & 12.6 \\
\hline Service Occupations & 8.2 & 9.9 & 11.6 & 10.3 & 11.6 & 12.6 & 12.9 & 13.2 & 13.0 & 15.7 \\
\hline Agricultural Occupations & 24.9 & 22.4 & 17.4 & 11.7 & 6.3 & 3.1 & 2.2 & 1.6 & 1.2 & 1.1 \\
\hline Farmer/Supervisory & 16.3 & 13.7 & 11 & 7.7 & 4.1 & 1.9 & 1.3 & 0.9 & 0.6 & 0.4 \\
\hline Farm Laborer & 8.6 & 8.6 & 6.4 & 4.1 & 2.2 & 1.3 & 0.9 & 0.7 & 0.6 & 0.7 \\
\hline \multicolumn{11}{|l|}{ Skill Groups } \\
\hline High Skill (Prof/Tech/Manager) & 12.4 & 14.7 & 15.7 & 17.9 & 20.7 & 23.4 & 27.8 & 33.3 & 37.6 & 39.4 \\
\hline $\begin{array}{l}\text { Middle Skill } \\
\text { (Clerical/Sales/Farmer/Craft) }\end{array}$ & 43.6 & 42.5 & 38.9 & 41.3 & 41.0 & 40.5 & 39.3 & 36.9 & 34.6 & 31.6 \\
\hline $\begin{array}{l}\text { Low Skill (Operative/Laborer/Farm } \\
\text { Laborer/Service) }\end{array}$ & 44.1 & 42.8 & 45.4 & 40.8 & 38.3 & 36.0 & 32.9 & 29.9 & 27.7 & 29.0 \\
\hline
\end{tabular}


Panel B: Manufacturing Industries

\begin{tabular}{|c|c|c|c|c|c|c|c|c|c|c|}
\hline Occupational Groups & 1920 & 1930 & 1940 & 1950 & 1960 & 1970 & 1980 & 1990 & 2000 & 2010 \\
\hline White Collar & 14.8 & 19.4 & 21.5 & 23.5 & 28.4 & 30.5 & 33.5 & 39.3 & 41.5 & 45.6 \\
\hline High Skill (Prof/Tech/Manager) & 6.1 & 8.2 & 7.9 & 9.7 & 13.0 & 15.3 & 18.1 & 23.9 & 27.6 & 31.7 \\
\hline Clerical/Sales & 8.7 & 11.2 & 13.6 & 13.9 & 15.4 & 15.2 & 15.5 & 15.4 & 13.9 & 13.9 \\
\hline Skilled Blue Collar (Craft) & 24.8 & 23.0 & 18.9 & 19.6 & 20.1 & 19.3 & 19.3 & 19.0 & 18.0 & 15.8 \\
\hline Middle Skill (Clerical/Sales/Craft) & 33.5 & 34.2 & 32.5 & 33.4 & 35.5 & 34.5 & 34.8 & 34.4 & 31.9 & 29.7 \\
\hline $\begin{array}{l}\text { Low Skill } \\
\text { (Operatives/Laborers/Service) }\end{array}$ & 60.4 & 57.6 & 59.5 & 56.9 & 51.4 & 50.2 & 47.2 & 41.7 & 40.5 & 38.6 \\
\hline
\end{tabular}

Sources: 1920 to 2000 Census of Population IPUMS and 2010 American Community Survey IPUMS.

Notes: Occupation shares are reported in percent. Occupations are classified into occupational groups based on 1950 occupation codes using the consistent coding of occupations in all years into 1950 codes (the OCC1950 variable) in the IPUMS. For 1930 to 2010 the samples include all individuals age 16 or older who were employed in the civilian workforce during the reference week for the Census or American Community Survey (EMPSTAT = 1 excluding those in the armed forces) and who reported a valid occupation (OCC1950 from 0 to 970). Employed individuals (those with EMPSTAT $=1$ ) are excluded from the sample as being members of the armed forces if they are categorized in the armed forces by the detail EMPSTAT codes (EMPSTAT = 13 in 1930 to 1950 and EMPSTAT = 14 or 15 in 1960 to 2010) or they list a military occupation (OCC1950 = 595). For 1920 the sample includes all individuals age 16 or older in the civilian labor force (LABFORCE $=2$ ) excluding those listing military occupations (OCC50=595). The 1940 Census occupation codes do not allow one to separate accountants (a professional occupation) from bookkeepers and cashiers (a clerical occupation) with all three groups being in occupation code 210 . We allocate individuals in 1940 occupation code 210 in the 1940 Census IPUMS into professionals (27.7 percent) and clerical occupations (72.3 percent) using the share of accountants among accountants, bookkeepers, and cashiers in the 1950 Census IPUMS sample. 


\section{Appendix A: Construction of Percent Unskilled: 1880 Manufacturing Sample}

The 1880 census reports sufficient data with which to compute an estimate of the average daily wage of workers at the establishment level (see Atack, Bateman, and Margo 2004). The census also inquired about the average daily of unskilled labor and the average daily wage of "mechanics". We use these data to construct a proxy for the percent skilled.

First, for firms that reported both types of wages, we use the following equation to estimate, $u$, the percent skilled

$w=w_{u} u+w_{s}(1-u)$

Here, $w$ is the average daily wage at the establishment level, $u$ is the share unskilled, and $s$ is the share of skilled blue collar. We compute the estimate of $u$ with this equation, retaining only those observations such that $u$ is non-negative. For firms that report the skilled wage but not the unskilled wage, we set $s=1$. For firms that report the unskilled wage but not the skilled, we set $\mathrm{s}=0$.

Our estimate of $u$ is clearly biased because our procedure assumes, in effect, that all employees were production workers, which is obviously incorrect. It is straightforward to show that our estimate of $u$ will be biased downwards. Let $\mathrm{m}$ be the share of non-production workers, and $w_{m}$ the average daily wage of non-production workers. Then the correct estimate of $u$ is given by the equation $u=\left(w-\left(w_{m}-w_{s}\right) m-w_{s}\right) /\left(w_{u}-w_{s}\right)$

Whereas our estimate is 
$u^{*}=\left(w-w_{s}\right) /\left(w_{u}-w_{s}\right)$

Both the numerator and denominator of the right hand side of the expression for $u$ or $\mathrm{u}^{*}$ are negative, but the numerator of the right hand side of $\mathrm{u}^{*}$ will be biased towards zero, hence our estimate of $\mathrm{u}^{*}$ will be smaller than the correct estimate, $\mathrm{u}$. However, this bias is likely to be very small, because $m$ was still relatively small for most establishments in 1880 . The bias will be increasing in absolute value as establishment size increases, so the coefficients on size in the regressions in Panel B of Table 4 are biased downwards. The downward bias reinforces the substance of our argument, namely that the percent of operatives/unskilled was increasing in establishment size.

\section{Appendix B: Construction of Occupation Distributions}

In Table 4 we present estimates of the occupation distribution in manufacturing and in the overall economy from 1850 to 1910 . Our estimates pertain to individuals ages 10 and over. The estimates are based on detailed adjustments to occupation distributions that are derived from the various IPUMS samples over the same period. IPUMS samples exist for every census year between 1850 and 1910, except 1890. The IPUMS occupation and industry data pertain to free persons aged 16 and over in the labor force; persons are considered to be in the labor force if they reported a gainful occupation.

\section{B1. Estimation of Occupation Distribution in Manufacturing}

The 1910 census was the first to ask individuals about their industry of employment as well as occupation. While there have been several attempts by scholars to produce estimates 
of the share of the labor force in manufacturing for the pre-1910 census years, to the best of our knowledge there have been no attempts to provide estimates of the occupation distribution within manufacturing.

Our estimates make use of the imputed IPUMS variable IND1950. The IPUMS staff created this variable after observing that in the census manuscripts individuals very frequently provided information recorded in the occupation column that readily identify the industry of employment. Nineteenth century census officials were long aware of this characteristic of the data collection; indeed, this was a primary reason why the census created the separate question in 1910. The IPUMS staff has devised a set of protocols to determine industry of employment based on the information contained in the census manuscripts (IPUMS-USA, undated). Importantly, these protocols were designed to provide a series that could link up to 1910, not to answer the question addressed in this paper. While we do not believe that the imputed industry classifications are accurate enough to produce reliable estimates of the occupation distribution at, say, the 3-digit SIC code, we do believe the classification is accurate enough to broadly distinguish the manufacturing and non-manufacturing labor force.

A small caveat to our estimates is that we make no adjustment for slave labor in manufacturing for 1850 or 1860 because we believe the available data to make such an adjustment is too sparse. Slaves were certainly employed in ante-bellum manufacturing; the best known example is the tobacco industry in Richmond, Virginia (Goldin 1976). Excluding slave biases downwards the share operative/unskilled in 1850 and 1860; however, the numbers 
are too small in the aggregate to noticeably alter the levels of the estimates, much less the trends that we observe.

As in our estimates for the overall occupation distribution (see below) we begin with samples of individuals drawn from the IPUMS with LABFORCE $=2$. We then retain all observations for which IND1950 indicates a manufacturing industry. Using the variable OCC1950, we classify the manufacturing labor force into white collar, skilled blue-collar, and operative/unskilled. This constitutes our preliminary distribution.

We make a series of adjustments to the preliminary distribution. In summary form, the adjustments are:

Re-allocation of Shoemakers and Operatives in Boots and Shoe Industry: see the discussion below.

Adjustment for Female Labor, 1850: the 1850 census reported occupations for males only. We assume that the ratio of males to the total manufacturing labor force, age 16 and over by occupation group (white collar, skilled blue collar, operative/unskilled) was the same in 1850 as in 1860. Applying these ratios to the IPUMS totals by occupation group in 1850, we produce estimates of the occupation distribution in manufacturing for both genders, age 16 and over.

Adjustment for Free Child Labor, Ages 10-15: for 1870-1910, we use the published census of manufacturing to compute the ratio of child workers (ages 10-15) to the sum of adult females and males. We multiply this ratio by the number of individuals in our preliminary occupation distribution; this generates an estimate of the number of child workers to be added to the total. 
We assume that all child workers are employed as operatives. For 1850 and 1860, we assume that the ratio of child workers to the sum of adult males and females was the same as in 1870 .

\section{B2. Estimation of Overall Occupation Distribution}

Our estimates of the overall occupation distribution do not rely on the imputed IPUMS variable IND1950, but do make use of the IPUMS variable OCC1950, which classifies occupations. We use this variable to divide up the labor force into seven occupation groups. The first five are non-farm occupations and the remaining two are farm: Professional/Technical, Managerial/Official/Proprietor, Clerical/Sales, Skilled Blue Collar, Operative/Unskilled/Service, Farm Operator/Supervisor, and Farm Laborer. The first three occupations are the traditional subdivisions of the white collar labor force. In Panel C of table 4, we present calculations that define the "unskilled" share of the labor force to be the sum of the shares in operative/unskilled/service and farm laborer.

For each IPUMS census year we begin by extracting a sample of individuals, selecting those for whom the variable $L A B F O R C E=2$ (in the labor force). All such individuals in the IPUMS are age 16 or over, and all report a gainful occupation. Using the variable OCC1950, we create a preliminary occupation distribution for the seven occupation groups listed above. We then make a series of modifications to the preliminary distribution. In summary form, these adjustments are:

\section{Adjustment for Free Female Labor Force, Age 16 and over, in 1850: the 1850 census only} reported occupations for free males. We make an initial imputation of the free female labor force by occupation group by assuming the ratio "Total Free Labor Force, Age 16 and over/Male 
Free Labor Force, Age 16 and over" was the same in 1850 and in 1860 . We then adjust the occupation group totals for females so that the overall gender composition matches Weiss's (2006, tables Ba1-10, Ba40-49) estimates for 1850.

Adjustment for laborers not elsewhere classified, living on farms, ages 16 and over: in the preliminary distribution, persons for whom OCC1950 = 970 (laborers, not elsewhere classified) are allocated to the operative/unskilled/service group, regardless of their residential location. However, it is widely believed by economic historians that such individuals who lived on farms were almost certainly farm laborers rather than non-farm. Therefore, the number of individuals who report OCC1950 $=970$ and also FARM $=2$ is subtracted from the operative/unskilled group and added to the farm laborer group.

Adjustment for Child Labor, free labor force: using Weiss (2006), we compute ratios by gender of the labor force age 10-15 to age 16 and over. We apply these ratios to the IPUMS sample totals, thereby generating estimates of children workers whose occupations were not reported in the labor force. Next, for each IPUMS census year, we extract a sample of individuals, ages 10-15, computing the proportion, by gender, who were living on farms (FARM $=2$ ). We multiply our estimated number of child workers by the share living on farms (by gender), and call the result the number of child workers employed in agriculture. We assume all such workers were farm laborers. The remainder is assigned to the operative/unskilled/service group.

Adjustment for Shoemakers and Operatives in Shoe Factories, 1850-1870: according to the 1850 and 1860 occupational classifications in the IPUMS, virtually all persons who were 
employed in the boot and shoe industry were classified as skilled artisans (shoemakers, or OCC1950 $=488)$ rather than operatives in shoe factories. However, according to the AtackBateman-Weiss samples from the manufacturing census, fully two-thirds of all labor employed in boots and shoes worked in establishments of sixteen or more workers - the commonly used definition of the "factory" - as early as 1850 . In the 1870 IPUMS sample, the proportion of operatives in boot and shoes is much closer to two thirds than in 1850 or 1860 . Consistent with the general trend towards factories, the proportion employed in boot and shoe establishments of 16 or more workers increased between 1850 and 1880, but the trend is a gentle one, not abrupt. We believe that in 1850 and 1860 the census had difficulty in distinguishing shoemakers in artisan shops from those working as operatives in establishments; the 1870 and 1880 censuses, however, contain instructions to enumerators to pay close attention to such distinctions in manufacturing. For 1850 to 1870 , therefore, we assume that 65 percent of workers age 16 and over in the boot and shoe industry were operatives, and 35 percent were skilled artisans. We adjust the preliminary occupation distribution in these years to reflect this assumption. For 1880, we assume that the occupation classification for persons in boots and shoes are correct, as indicated by OCC1950.

Adjustment for Slave Occupations, 1850 and 1860: We use Weiss (2006) estimates to calculate, by gender, the ratio, "Slave Labor Force/Free Labor Force". We apply these ratios to the adjustment number of free workers, by gender (i.e. the adjustments described above). This generates an estimate number of slave workers, to be included in our occupation distributions. We use Olson (1992, p. 139, table 8.1) to allocate our estimated number of slave workers to the occupation groups. For men this results in allocations to the skilled artisan, 
operative/unskilled/service, farm operator/supervisor, and farm laborer groups; for women, the allocations are to operative/unskilled/service and farm laborer. It is likely that this procedure underestimates the number of skilled artisans among male slaves because the Olson table is based on probate and plantation records and, as such, probably under-weights slaves in urban areas; however, any bias is likely to be very small, because the share of slaves in urban areas was less than 5 percent in the decade before the Civil War (Goldin 1976).

\section{Appendix C: Construction of Wage Series, 1866-1880}

We provide annual estimates of nominal wages for three occupations: common labor, artisans, and white collar workers (clerks). The data source is the Reports of Persons and Articles Hired (Record Group 92, National Archives) used extensively by Margo (2000) in his construction of analogous wage series for the antebellum period. The data pertain to civilians hired at US army installations, and cover the period 1866-1880. The data were extracted (by hand) from monthly payrolls at the forts which have survived and have been deposited at the National Archives. There are approximately 17,000 wage observations available in the data set (a wage observation refers to a person month, for example, a carpenter hired at St. Louis for one or more days during the month of October in 1879). Like those for the antebellum period, the data appear to reflect labor market conditions in the labor market surrounding the fort.

Wage series are produced from hedonic regressions. In these regressions, the dependent variable is the logarithm of the daily wage (if a worker is hired on a monthly basis, the daily wage is computed by dividing by an assumed 26 days of labor per month). Control variables include occupation dummies, month of the year, place of hire (or state in which the 
fort is located), other characteristics of the worker if known (e.g. race), and year. ${ }^{33}$ For common labor and artisans the regressions are estimated separately by region. For white collar workers the number of observations is insufficient to estimate regional series and instead a national regression is estimated with extensive controls for location.

From the year dummies we produce annual indices of nominal wages. These annual indices are then benchmarked to wage estimates from other sources (see Margo 2002, 2004, and the text of the current paper). For common labor the benchmarking is extensive (multiple years between 1866 and 1880) and the year by year values of the indices are adjusted to reflect the benchmarking.

The data for common labor has previously been analyzed, and annual wage series for census regions (Northeast, Midwest, South Atlantic, and South Central) produced in Margo (2002, 2004). Except for California during the Gold Rush period (see Margo 2000) no series have been produced for the western United States.

For this paper we estimated annual series of daily wages for artisans by region and an annual series for white collar workers (see above regarding the white collar regression). For common labor and artisans we aggregated the regional series using region-specific weights. To compute these weights we drew extracts from the 1870 and 1880 IPUMS samples and estimated regional shares of occupations for 1870 and 1880 . We linearly interpolated the shares between 1870 and 1880 . For $1866-69$ we used the 1870 weights.

\footnotetext{
${ }^{33}$ In some cases the year dummies refer to groups of years rather than single years. In such cases we linearly interpolate to produce the annual series.
} 